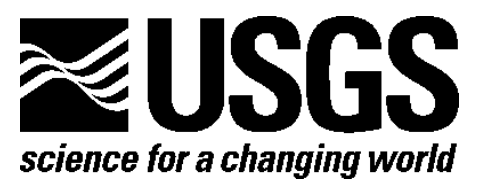

Prepared as part of a Technical Assistance Agreement with Sound Transit

\title{
Assessing Landslide Potential on Coastal Bluffs near Mukilteo, Washington-Geologic Site Characterization for Hydrologic Monitoring
}

By Benjamin B. Mirus, Joel B. Smith, Benjamin Stark, York Lewis, Abigail Michel, and Rex L. Baum

Open-File Report 2016-1082

U.S. Department of the Interior

U.S. Geological Survey 


\section{U.S. Department of the Interior \\ SALLY JEWELL, Secretary}

\section{U.S. Geological Survey \\ Suzette M. Kimball, Director}

U.S. Geological Survey, Reston, Virginia: 2016

For more information on the USGS—-the Federal source for science about the Earth,

its natural and living resources, natural hazards, and the environment-visit

http://www.usgs.gov/ or call 1-888-ASK-USGS (1-888-275-8747).

For an overview of USGS information products, including maps, imagery, and publications, visit http://store.usgs.gov.

Any use of trade, firm, or product names is for descriptive purposes only and does not imply endorsement by the U.S. Government.

Although this information product, for the most part, is in the public domain, it also may contain copyrighted materials as noted in the text. Permission to reproduce copyrighted items must be secured from the copyright owner.

Suggested citation:

Mirus, B.B., Smith, J.B., Stark, Benjamin, Lewis, York, Michel, Abigail, and Baum, R.L., 2016, Assessing landslide potential on coastal bluffs near Mukilteo, Washington-Geologic site characterization for hydrologic monitoring: U.S. Geological Survey Open-File Report 2016-1082, 28 p., http://dx.doi.org/10.3133/ofr20161082.

ISSN 2331-1258 (online) 


\section{Preface}

The work described in this report was undertaken as part of a Technical Assistance Agreement between the U.S. Geological Survey and Sound Transit to investigate landslide hazards affecting the railway corridor along the eastern shore of Puget Sound between Seattle and Everett, Washington. This report presents preliminary results of geologic site characterization and describes a hydrologic monitoring system located near Mukilteo, Washington. The long-term objectives of this work are to improve understanding of the linkages between rainfall characteristics and hydrologically induced landslide initiation processes, and to provide information that will aid Sound Transit in the development of a prototype near-real-time landslide hazard assessment system along the railway corridor. This report provides partners and stakeholders with preliminary information on site selection, characterization, and monitoring equipment, but it is not a product that can be directly implemented for landslide hazards assessments. 


\section{Acknowledgments}

This report was prepared through a Technical Assistance Agreement with Sound Transit (ST), Seattle, Washington, under agreement \#15WNTAASNDTRNST_00. All equipment was installed on the City of Mukilteo's property with permission and access to these sites established through Temporary Right of Entry and License Agreements with the City of Mukilteo and the Home Owners Associations of One Club House Lane Sector 12 and Waterton at Harbour Pointe. Logistical support for site access and equipment procurement was provided by Jeff Chou of ST. Laboratory analysis of specimens at the Colorado School of Mines were conducted in the Unsaturated Soil Mechanics Laboratory. The authors are grateful for the helpful review comments and suggestions from USGS colleagues, Jonathan Godt, Mark Reid, and Jeff Coe, on an earlier version of this work. 


\section{Contents}

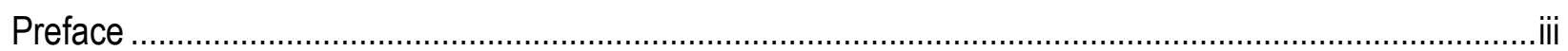

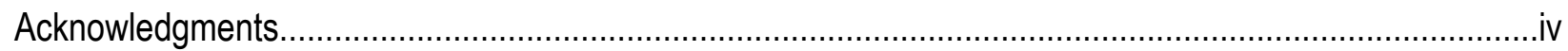

Abstract ………

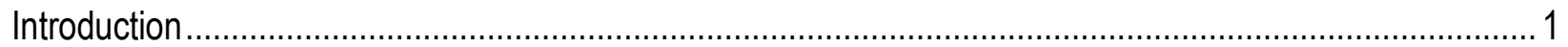

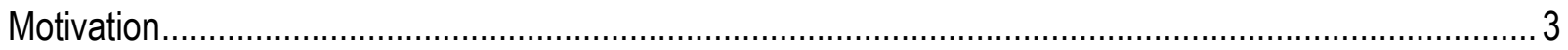

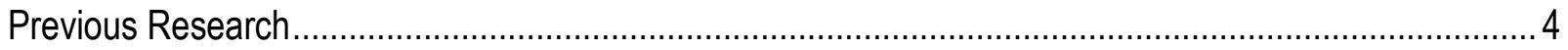

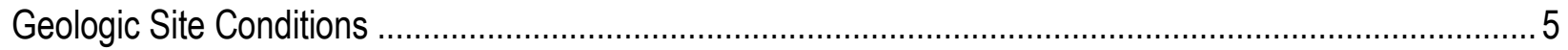

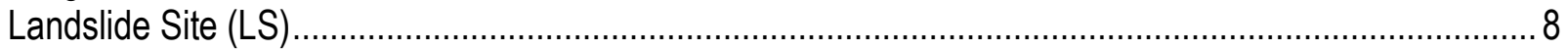

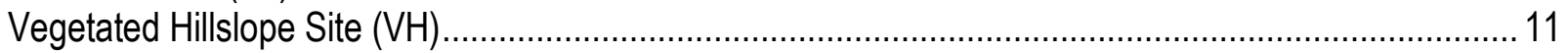

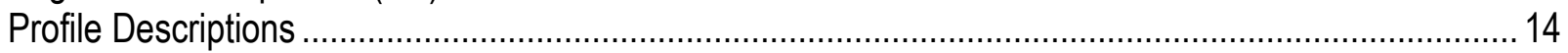

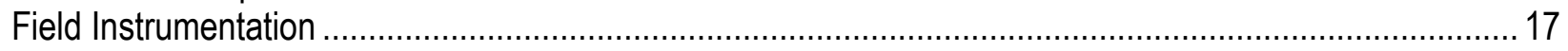

Laboratory Analyses of Colluvium and Glacial Sediments.............................................................. 18

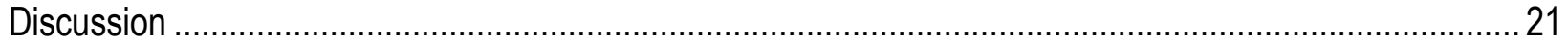

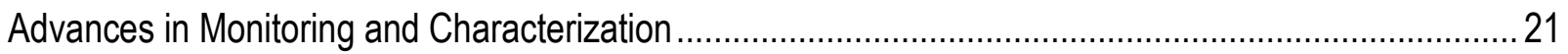

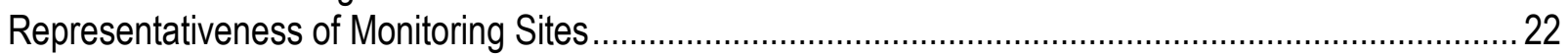

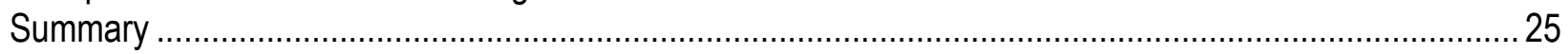

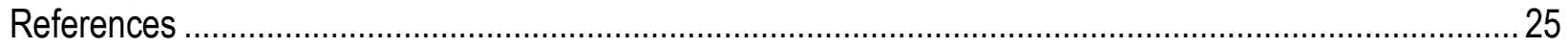

\section{Figures}

1. Regional map of study area in Puget Sound, Washington, showing monitoring sites (LS, VH, M1, and M2)

2. Longitudinal cross section through the $A, \mathrm{LS}$; and $B$, VH monitoring sites derived from 0.5 -meter $(\mathrm{m})$ resolution lidar data. The five locations of instrument clusters and specimen collection are shown, which correspond to the photographs in figs. 3 and 4 . Inserts on each transect show enlarged view of location 1 at each site. Instrumentation and specimen collection details are summarized in tables 4 and 5 , respectively.

3. Photographs and descriptive logs of the LS site: $A$, exposure of glacial deposits on head scarp at location $1 ; B$, pit excavated at the base of the head scarp at location $1 ; C$, pit excavated in landslide deposits below the head scarp at location 1; $D$, exposure of glacial deposits on southern flank scarp at location 2; $E$, pit excavated at location 2 below the northern flank of the landslide; $F$, pit excavated in the landslide deposit at location $3 ; G$, pit excavated in the landslide deposit at location 4 ; and $H$, pit excavated in the landslide deposit at location 5. Locations are shown on fig. $2 A$, instrumentation is summarized in table 4 , and specimen details are provided in table 5 .

4. Photographs and descriptive logs of the VH site: $A$, exposure of in-situ glacial deposits along incised stream channel and step pool at approximate elevation of location 2; $B$, detail of exposed glacial deposits in incised channel at approximate elevation of location $5 ; C$, pit excavated in colluvium at location $1 ; D$, pit excavated in colluvium at location 2 ; $E$, pit excavated in colluvium at location $3 ; F$, pit excavated in colluvium at location 4 ; and $G$, pit excavated in colluvium at location 5 . Elevations of locations are shown on fig. $2 B$, instrumentation is summarized in table 4 , and specimen details are provided in table 5 (cm, centimeter)...... 
5. Cohesion, internal angle of friction, saturated hydraulic conductivity, and bulk density values reported for other similarly aged glacial deposits in Everett and Seattle (Godt and McKenna, 2008; Savage and others, 2000b) compared to laboratory measurements conducted on specimens from this study. Results for specimens from this study are shown in lighter gray on the left hand side for the LS and in darker gray circles on the right hand side for the VH site ... 24

\section{Tables}

1. Descriptive summary of glacial deposit exposures at the LS site 14

2. Descriptive summary of pits excavated into landslide deposits at the LS site... 15

3. Descriptive summary of pits excavated into colluvium at the $\mathrm{VH}$ site 16

4. Summary of instrumentation and specimen collection for each site location (see figs. 1 and 2)..... 17

5. Summary of specimen collection location and depth, geologic material, physical descriptions, laboratory testing facility, and corresponding figure.

6. Summary of particle size distributions and physical properties of selected specimens ..................220

7. Hydraulic properties and plasticity of selected specimens ...................................................... 20

8. Unsaturated hydraulic properties determined using the Transient Water Release and Imbibitions Method (TRIM) for selected specimens ............................................................................ 21

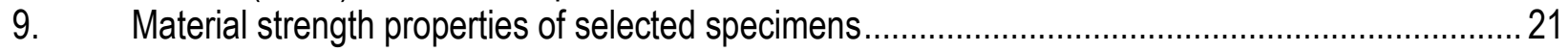




\title{
Assessing Landslide Potential on Coastal Bluffs near Mukilteo, Washington-Geologic Site Characterization for Hydrologic Monitoring
}

By Benjamin B. Mirus, ${ }^{1}$ Joel B. Smith, ${ }^{1}$ Benjamin Stark, ${ }^{1,2}$ York Lewis, ${ }^{3}$ Abigail Michel,,${ }^{1,3}$ and Rex L. Baum ${ }^{1}$

\begin{abstract}
During the summer 2015, the U.S. Geological Survey collected geologic and geotechnical data for two sites on coastal bluffs along the eastern shore of Puget Sound, Washington. The U.S. Geological Survey also installed hydrologic instrumentation at the sites and collected specimens for laboratory testing. The two sites are located on City of Mukilteo open-space land and are about 0.6 kilometers apart. The bluffs at each site are approximately 42 meters high, and rise steeply from the shoreline with $32-35^{\circ}$ slopes. The more northerly of the two sites occupies an active landslide and is mostly unvegetated. The other site is forested, and although stable during the preparation of this report, shows evidence of historical and potential landslide activity. The slopes of the bluffs at both sites are mantled by a thin, nonuniform colluvium underlain by clay-rich glacial deposits and tills of the Whidbey Formation or Double Bluff Drift. Till consisting of sand, gravel, and cobbles caps the bluffs and rests on finer grained glacial deposits of sand, silt, and clay. These types of different glacial deposits are dense, vertically fractured, and generally have low permeability, but field observations indicate that locally the deposits are sufficiently permeable to allow lateral flow of water along fractures and subhorizontal boundaries between deposits of different texture. Laboratory tests indicate that many of the deposits are highly plastic, with low hydraulic conductivity, and moderate shear strength. Steep slopes combined with the strength and hydraulic characteristics of the deposits leave the bluffs prone to slope instability, particularly during the wet season when infiltrating rainfall changes moisture content, pore-water pressure, and effective stress within the hillslope. The instrumentation was designed to primarily observe rainfall variability and hydrologic changes in the subsurface that can affect stability of the bluffs, and also to compare the hydrologic response between areas where previous landslides have disturbed vegetation and areas where the bluff is apparently more stable and well vegetated.
\end{abstract}

\section{Introduction}

The greater Puget Sound region of Washington (fig. 1), is subject to a variety of landslide types (Baum and others, 2005a), including (1) large, deep, translational and rotational earth slides, (2) soil topples and associated soil and rock falls, (3) shallow translational slides, and (4) debris flows and rapid earth flows. Whereas large, deep-seated landslides can be tens of meters deep and cause extensive

\footnotetext{
${ }^{1}$ U.S. Geological Survey.

${ }^{2}$ Giles Engineering Associates.

${ }^{3}$ Colorado School of Mines.
} 
damage (Savage and others, 2000a; Schulz, 2004; Brien and Reid, 2008), they occur relatively infrequently (every few years). Similarly, soil topples and rock falls are relatively rare and typically only cause minimal damage in highly localized areas. In contrast, smaller, shallow translational slides are typically less than 3 meters $(\mathrm{m})$ deep, but occur with the greatest frequency (multiple times a year) (Godt and others, 2006, 2008a; Harp and others, 2006). Furthermore, debris flows and rapid earth flows in the Puget Sound area generally mobilize from shallow landslides, so these types of slope failures are related in terms of their triggering mechanisms. Although without historical precedence, earthquakes could trigger widespread landsliding in the Seattle area (Allstadt and others, 2013), but the emphasis of this report is on shallow landslides triggered by heavy or sustained rainfall (Godt and others, 2006). Two factors motivate this emphasis: (1) decades of monitoring rainfall conditions leading to these shallow slope failures has confirmed that they occur nearly every year in the Puget Sound area (for example Baum and others, 2000; Laprade and Tubbs, 2008); and (2) the timing, duration, and intensity of such rainfall conditions can be predicted with reasonable accuracy. These factors enable the development of empirical threshold criteria (Chleborad and others, 2006, 2008), which could be used for probabilistic early warning of rainfall-induced landslides.

The coastal bluffs along the eastern shore of Puget Sound between Everett and Seattle (fig. 1) are particularly prone to episodic, shallow, hydrologically induced landslides that pose a safety hazard to private and public property. For example, during the winters of 1996-1997 and 2005-2006 numerous landslides resulted in widespread damage (Baum and others, 1998, 2000; Godt and others, 2009). Below these hillsides, Sound Transit (ST) operates a commuter rail service, which experiences costly interruptions or cancellations of passenger service when landslides temporarily block the railway tracks. Therefore, ST and its partners, Washington Department of Transportation (WSDOT), Burlington Northern Santa Fe Railway (BNSF), and Amtrak, are all concerned with the safety of railway operations and recognize an urgent need to mitigate landslide hazards. BNSF and WSDOT have recently constructed engineered mitigation works at selected locations (http://www.wsdot.wa.gov/projects/rail/slidemanagement/), but in parallel to these engineering efforts ST also intends to set up and operate a demonstration hydrologic monitoring system to aid in assessing the timing of elevated landslide potential.

In 2015, a Technical Assistance Agreement between the U.S. Geological Survey (USGS) and ST was established to initiate a provisional one-year study. The practical objective of this effort is to inform the development and testing of criteria for landslide early warning for the Puget Sound railway corridor. These criteria can serve as tools for managers to reduce and better manage service interruptions and minimize risks to people and property. The scientific objective of this effort is to quantify how shallow landslide initiation relates to precipitation and subsurface hydrologic response. As part of the agreement, the USGS conducted detailed geologic characterization of two sites and installed a near-real-time monitoring system along the coastal bluffs in the City of Mukilteo, Washington (fig. 1).

The monitoring system includes precipitation measurements at multiple locations and subsurface hydrologic-response instrumentation at two landslide-prone sites. The two paired sites with subsurface instrumentation are underlain by similar geology and slope conditions. One site is situated within a recent landslide (LS) and the other is located on a densely vegetated hillslope (VH) that remained stable for the duration of this investigation. Given that the underlying glacial deposits and steep slope of both bluffs are essentially the same, the $\mathrm{VH}$ also has the potential to become unstable in the future. This report provides (1) motivation and previous work related to understanding shallow landslide initiation and establishing criteria for landslide warning systems in the Puget Sound area, (2) a description of geologic conditions and soil properties documented at the two instrumented sites, (3) a brief summary of instrument types and locations, (4) the results from laboratory analyses of specimens collected at both 
sites, and (5) a discussion of the efforts presented here, including the advances in monitoring and characterization relative to previous efforts and the representativeness of the two monitoring sites relative to general conditions reported for other landslide-prone areas in Puget Sound.

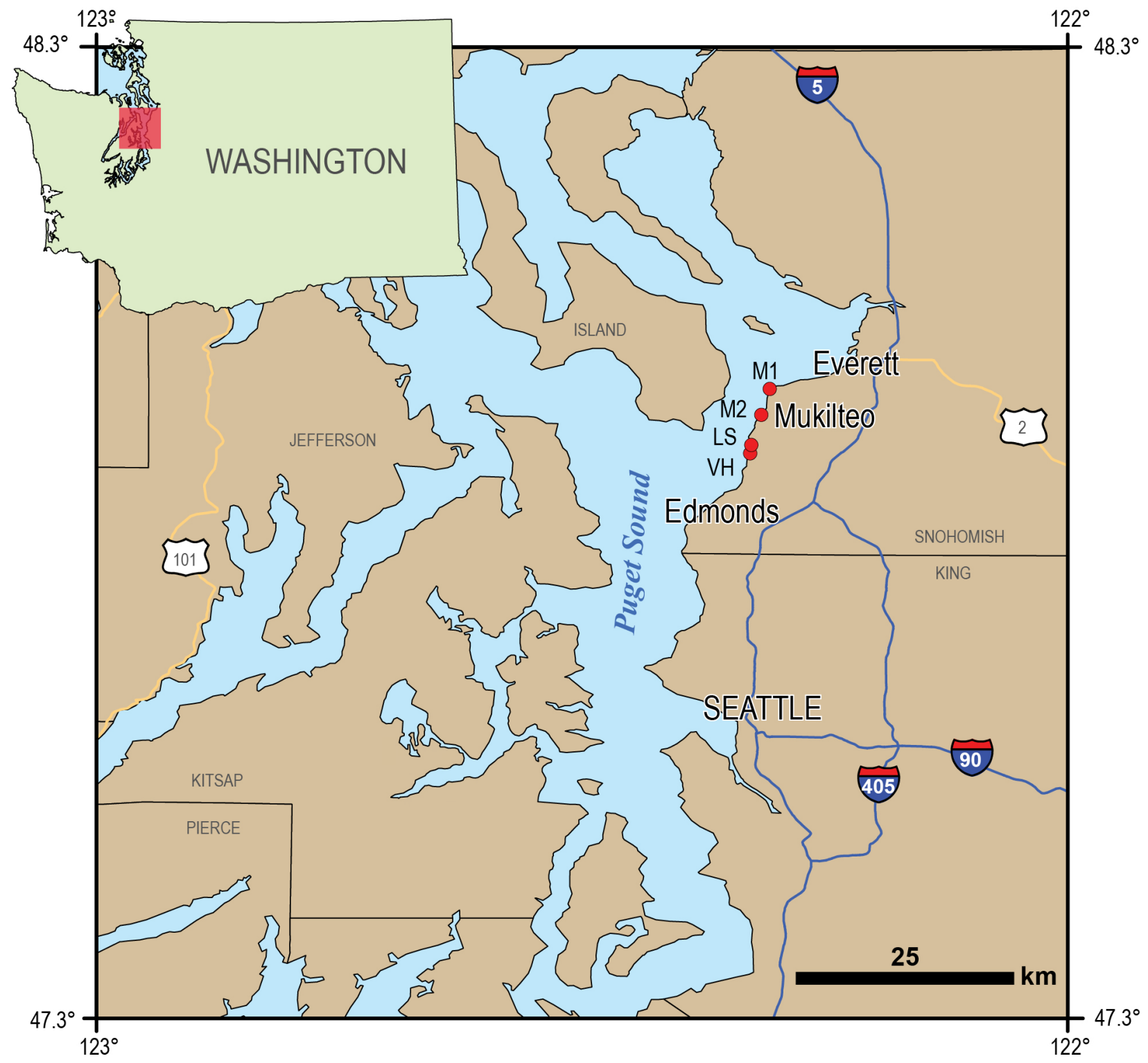

Figure 1. Regional map of study area in Puget Sound, Washington, showing monitoring sites (LS, VH, M1, and M2) (modified from Baum and others, 2005b).

\section{Motivation}

Some shallow landslides and associated debris flows are large enough to block tracks and shut down operations while debris is cleared from the railway. Additionally, reactivation of existing slides during large storms is common. For example, of the 132 recent and historic landslides inventoried for 
this region of Puget Sound, 9 were described as being associated in some way with historical landslides (Baum and others, 2000). Therefore, recent slides are often monitored by the rail partners for further activity during the rainy season, until engineering works or revegetation have been deemed to sufficiently stabilize the slope. Past practice in operation of the Seattle-Everett rail corridor has focused on avoiding damage and losses due to landslides through use of a trip-wire notification system as well as engineered works such as drainage and retaining structures. Trip wires located below some of the most failure-prone hillsides alert the railway owner, BNSF, when and where landslides have occurred so that operations can be suspended until the tracks have been cleared of debris. In recent years BNSF has also imposed a 48-hour long waiting period for passenger traffic after the occurrence of a landslide, largely to avoid losses from additional slope failures that may occur at other locations along the bluffs, but also to ensure that the landslide does not remobilize. Although this practice has helped to enhance the safety of railway operations, large numbers of landslides along the corridor have resulted in frequent cancellations of passenger service, as well as derailment of a freight train near Everett in mid-December 2012 and derailment of an Amtrak passenger train on April 7, 2013 (Sheets, 2013). Past observations, for example in 2006 (Godt and others, 2009), indicate that landslides sometimes initiate after rainfall has ceased and continue to occur over several days. This uncertainty about timing relative to rainfall makes it difficult to decide when the immediate threat of landslides has ended. Consequently, standard practice of waiting 48 hours may be inadequate to ensure passenger safety and limit damage resulting from landslides. Improved understanding of the conditions that can cause previous landslides to reactivate, conditions that cause stable bluffs to fail, and any potential differences between the two, could inform additional refinements to railway operations and help further reduce potential losses related to landslides.

Development and operation of a demonstration landslide early warning system is part of a strategy that ST engineers have proposed to mitigate landslide problems and improve safety, and is designed to supplement recently constructed landslide mitigation measures. Using precipitation thresholds and hydrologic observations to assess the time-varying potential for landslides is considered an important strategy for managing landslide risk along the corridor, in part because construction of mitigation works, including drainage enhancement and slope reinforcement along the entire corridor between Seattle and Everett (over 40 kilometers [km]), would be cost prohibitive. Additionally, improved understanding of landslide thresholds and subsurface hydrology will ultimately help in the engineering of cost-effective mitigation strategies.

\section{Previous Research}

Following damaging landslides in January and March 1997, the USGS began cooperative efforts with City of Seattle and Shannon and Wilson, Inc. to evaluate spatial and temporal aspects of landslide occurrence in Seattle (Baum and others, 2000; Chleborad, 2000, 2003; Coe and others, 2004; Godt and others, 2006; Harp and others, 2006; Salciarini and others, 2008). The USGS developed empirical rainfall thresholds for early identification of the conditions leading to landsliding in the Seattle area, and has continued to post hourly rainfall amounts with respect to these thresholds on the Landslide Hazards Program Web site (http://landslides.usgs.gov/monitoring/seattle/rtd/). In 2001, the USGS partnered with the WSDOT, BNSF, and its geotechnical consultant, Shannon and Wilson, Inc., to monitor two landslide-prone bluffs adjacent to the railway, one in Edmonds and the other in Everett (Baum and others, 2005b).

In the winter season of 2006, USGS monitoring equipment in Edmonds measured hydrologic conditions leading to shallow landslides. In January of 2006, a small shallow landslide (25 m long, $11 \mathrm{~m}$ wide, and less than two meters deep) damaged the monitoring equipment at the Edmonds site 
(Godt and others, 2009). The five-year monitoring effort (2001-2006) led to improved understanding of hydrologic response and shallow landslide initiation on the coastal bluffs (Godt and others, 2006; Godt and McKenna, 2008). The USGS also partnered with the Colorado School of Mines to make advances in laboratory testing and analysis of unsaturated soil mechanics and hydrology ( $\mathrm{Lu}$ and Godt, 2008; Godt and others, 2009; Lu and others, 2010, 2011), and has applied these methods to understanding shallow landslide initiation processes in Seattle and elsewhere (Godt and others, 2008a; Lu and Godt, 2013). Additionally, the USGS has developed a computer model for simulating rainfall infiltration and slope stability over wide areas (Baum and others 2008, 2010) and has demonstrated its potential for application to landslide-prone coastal bluffs near Mukilteo (Godt and others, 2008b) and elsewhere (Baum and others, 2010).

By tracking current and recent rainfall, the thresholds for Seattle provide a means to estimate the likelihood of landslide activity in the Seattle area on any given day (Chleborad, 2000, 2003). Precipitation in the Puget Sound region has a marked seasonal variation, with most precipitation falling from mid or late October through March. At the end of the summer, soil is typically dry (that is, below field capacity) and moisture levels increase during the early part of the rainy season; consequently, antecedent rainfall is an important factor in determining landslide susceptibility throughout the rainy season. The USGS has defined several methods to account for antecedent precipitation, one being an antecedent water index (AWI) (Godt and others, 2006) and the other being a cumulative precipitation threshold that considers precipitation during the previous 18 days by comparing precipitation during the last 3 days against precipitation from the 15 days prior (Chleborad, 2000). Historical data indicate that 85 percent of days on which one or more landslides occurred have exceeded this threshold. The AWI tracks cumulative rainfall, estimated evapotranspiration, and estimated soil water drainage to indicate relative soil moisture levels.

The USGS has also defined a rainfall intensity and duration threshold that accounts for total storm rainfall and total storm duration (Chleborad and others, 2006, 2008). With the exception of rainon-snow occurrences in which rapid snowmelt contributed significantly to landsliding triggered by infiltrating water, rainfall leading up to most widespread landslides (for example, greater than 50) in and near Seattle have exceeded the thresholds, but these thresholds are not useful for predicting when isolated landslides (that is, only one or two) are likely (Godt and others, 2006). A lower intensity and duration threshold (40 millimeters in 24 hours) has been identified for extended (weeks-long) rainfall, such as occurred during December 2005-January 2006 (Chleborad and others, 2008; Baum and Godt, 2010).

Implementation of landslide early warning systems across the United States has the potential to reduce the effect of landslides (Baum and Godt, 2010). However, further site-specific testing of a general theoretical framework, development and refinement of landslide initiation models, operational collection and analysis of near-real-time hydrologic data, and integration with operational weather forecasting is needed to facilitate more widespread implementation (NOAA-USGS Debris Flow Task Force, 2005). The work described here will contribute to further site-specific testing of landslide initiation models, as well as to enhancing capabilities for collecting and interpreting near-real-time hydrological data in landslide-prone terrain.

\section{Geologic Site Conditions}

The coastal bluffs along the eastern shore of Puget Sound between Seattle and Everett are underlain by subhorizontally bedded glacial advance outwash sands and underlying glaciolacustrine silts (Minard, 1983). Shallow landslides in these weathered glacial deposits and overlying colluvium are common after periods of heavy rainfall and (or) snowmelt infiltration (Baum and others, 2000; 
Chleborad and others, 2006, 2008; Godt and others, 2006). The presence of localized seeps and springs along the bluffs suggests that infiltrated water perches on low permeability layers of silt or clay and flows laterally through overlying sandy or gravelly layers, and this perching may contribute to pore pressure buildup and slope failures in some locations (Tubbs, 1974; Baum and others, 2005b).

The investigation presented here focused specifically on the coastal bluffs near the City of Mukilteo (fig. 1), where landslides regularly affect railway traffic and also threaten private roadways and residences. The bluffs in this general area straddle a mapped transition between the Whidbey Formation and the underlying Double Bluff Drift (Minard, 1983), which are both Pleistocene age deposits of glaciolacustrine and glaciomarine sand, gravel, lodgement till, silt, and clay. The Whidbey Formation ranges from 151,000 to 96,000 years (Booth and others, 2003). Minard (1983) describes the Whidbey Formation as largely compacted cross-bedded medium- to coarse-grained sand with considerable oxidation, and he notes that contorted bedding is a common structural feature. In the lower portion of the Whidbey Formation, dense, clay-rich beds restrict percolation of groundwater, resulting in perched saturation within the overlying sands, which may contribute to slope failure where this contact is exposed along the bluffs (Minard, 1983).

The Double Bluff Drift is the oldest unit in the Mukilteo quadrangle ranging between 291,000 and 111,000 years (Booth and others, 2003). It also contains a basal layer of thinly bedded clays and silts containing wood, overlain by hard, sandy till and (or) sparsely pebbled, vertically jointed silty clayey marine glacial sand (Minard, 1983). These grade up into sections of gravelly till and crudely bedded sand and gravel, which in turn locally grade up into a massive lodgement till (Minard, 1983). The Double Bluff Drift is prone to slope failures along the vertically jointed planes in the till and marine glacial beds, particularly when the underlying sand and gravel beds are undermined by wave action from Puget Sound (Minard, 1983). Indeed, the importance of toe erosion by surface water has been identified as an important mechanism in historical landslides across Seattle (Schulz, 2007; Schulz and others, 2008). However, along the eastern shore of Puget Sound, construction of the railway line has provided protection from wave attack at the base of the bluffs, which has likely reduced erosion at the toe of these slopes and thus reduced the effect of undercutting on slope stability. Without wave erosion along the base of the bluffs, landslide initiation along the railway corridor between Seattle and Everett is likely dominated by infiltration-induced pore-pressure increases and changes in effective stress in the shallow subsurface (less than $3 \mathrm{~m}$ depth). Of particular interest to landslide initiation are contacts between relatively permeable sand and underlying low-permeability clay units, or contacts between more permeable colluvium and underlying glacial deposits.

Two sites (LS and VH, fig. 1) were selected for detailed geologic characterization and monitoring to facilitate a paired study of hydrologic conditions on a sparsely vegetated recent landslide scar (LS) and a densely vegetated bluff (VH). Assessment of the site conditions at each of these two locations included general characterization of the exposed geology and detailed documentation of the stratigraphy in several shallow pits, which were dug by hand in the colluvium. Additionally, specimens of the colluvium and glacial deposits at each site were collected for laboratory analysis of physical, hydraulic, and geotechnical properties. For each monitoring site, five evenly spaced locations along a longitudinal transect (from near the top of the bluff down towards the bottom at the toe) were selected for instrument clusters and specimen collection (fig. 2). Photographs of the pits excavated into colluvium and exposures of the underlying glacial deposits are shown in figures 3 and 4 . The following subsections include general characterization of both sites, and descriptions of stratigraphy observed in these pits and glacial deposit outcrops. 

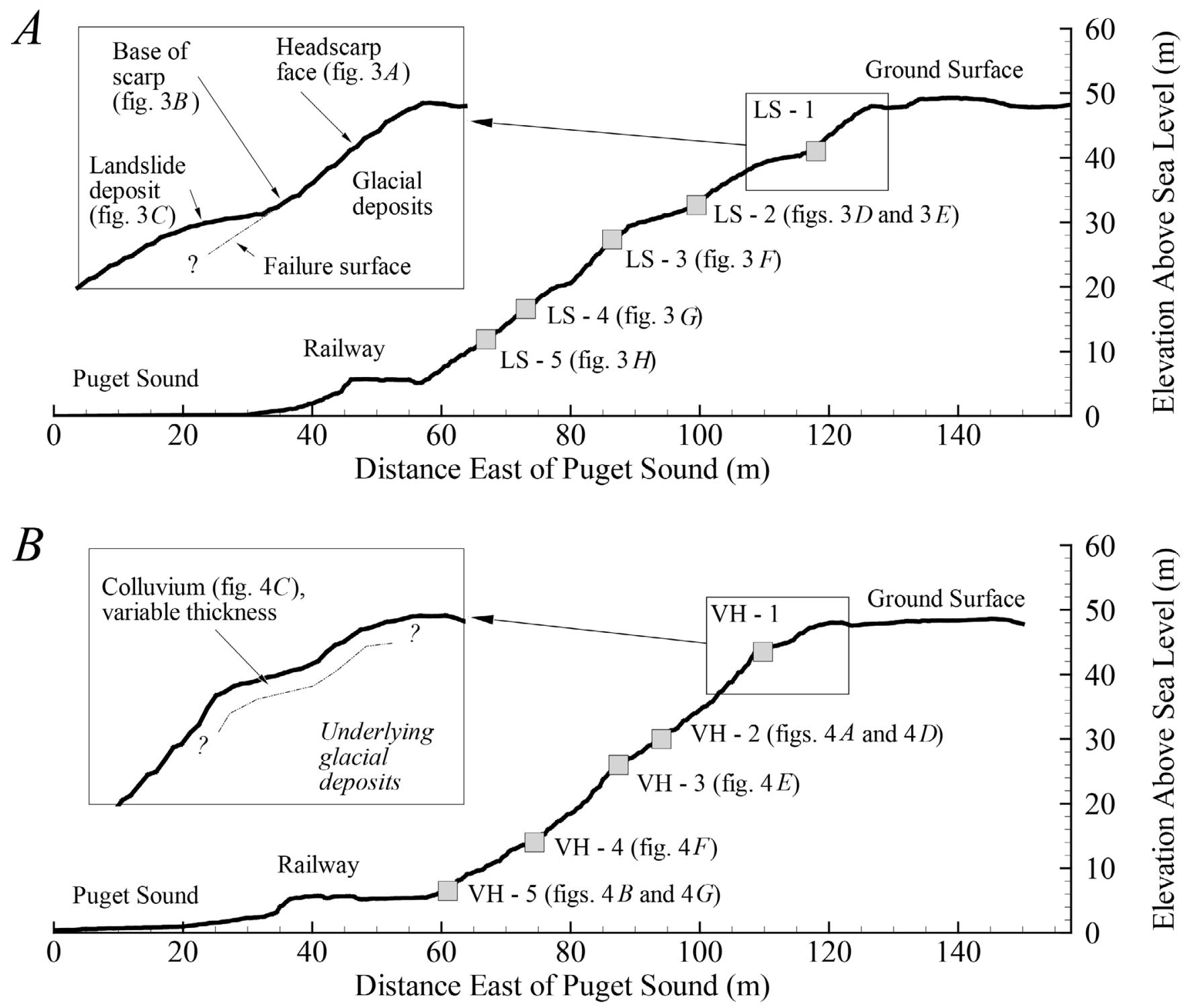

Figure 2. Longitudinal cross section through the $A$, LS; and $B$, VH monitoring sites derived from 0.5 -meter $(\mathrm{m})$ resolution lidar data. The five locations of instrument clusters and specimen collection are shown, which correspond to the photographs in figs. 3 and 4. Inserts on each transect show enlarged view of location 1 at each site. Instrumentation and specimen collection details are summarized in tables 4 and 5 , respectively. 


\section{Landslide Site (LS)}

The LS site (figs. 1 and $2 A$ ) is located on City of Mukilteo open-space property above the railway access line and was accessed by a Right of Entry (ROE) agreement between the USGS, ST, the City of Mukilteo, and the adjacent Home Owners Association (HOA) of Waterton at Harbour Pointe. The residents of this HOA reported that in 2013 substantial engineering and drainage work was completed to divert surface ponding from above the unstable bluffs towards a deep drainage ravine, which is approximately $0.1 \mathrm{~km}$ southward of the slide. The slide also initiated during the winter 2013, but onsite investigation revealed tension cracks and unvegetated landslide deposits that suggest it has likely undergone additional displacement since 2013.

The average slope of the bluff at the LS site is 32 degrees, and the relief of the bluff above the railway line is $42 \mathrm{~m}$ (fig. $2 A$ ). The head scarp of the slide has exposed a very thin (less than 5 centimeters $[\mathrm{cm}]$ ) organic-rich sandy soil horizon and the upper part of the underlying glacial deposit stratigraphy (fig. $3 A$ ). The uppermost layer of the bluff is composed of a gravelly till and poorly graded sand, gravel, and cobbles, which grades downward into gravelly sand. Underlying this gravel and cobble-rich till deposit is a dense, clay-rich silty yellowish-gray till layer with numerous vertical and horizontal linear or planar features. Underlying this silty till is a dense, hard light-gray homogeneous fine sand, which is exposed on the left flank scarp (southern edge) of the landslide (fig. $3 A$ ). Below this fine sand layer, recently active slide deposits have covered the lower portion of the bluff (figs. $3 A, B$, and $C$ ). 

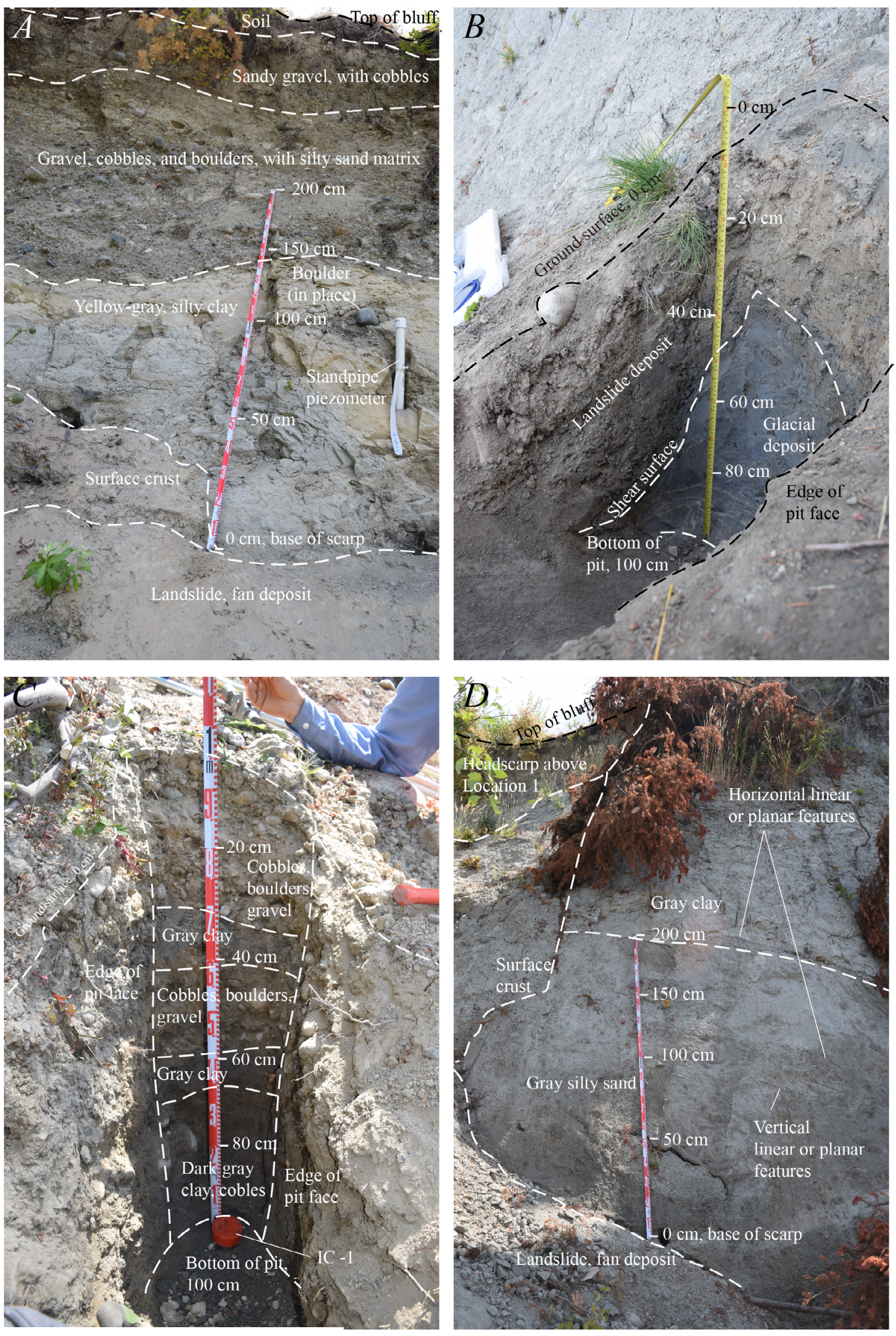

Figure 3. 

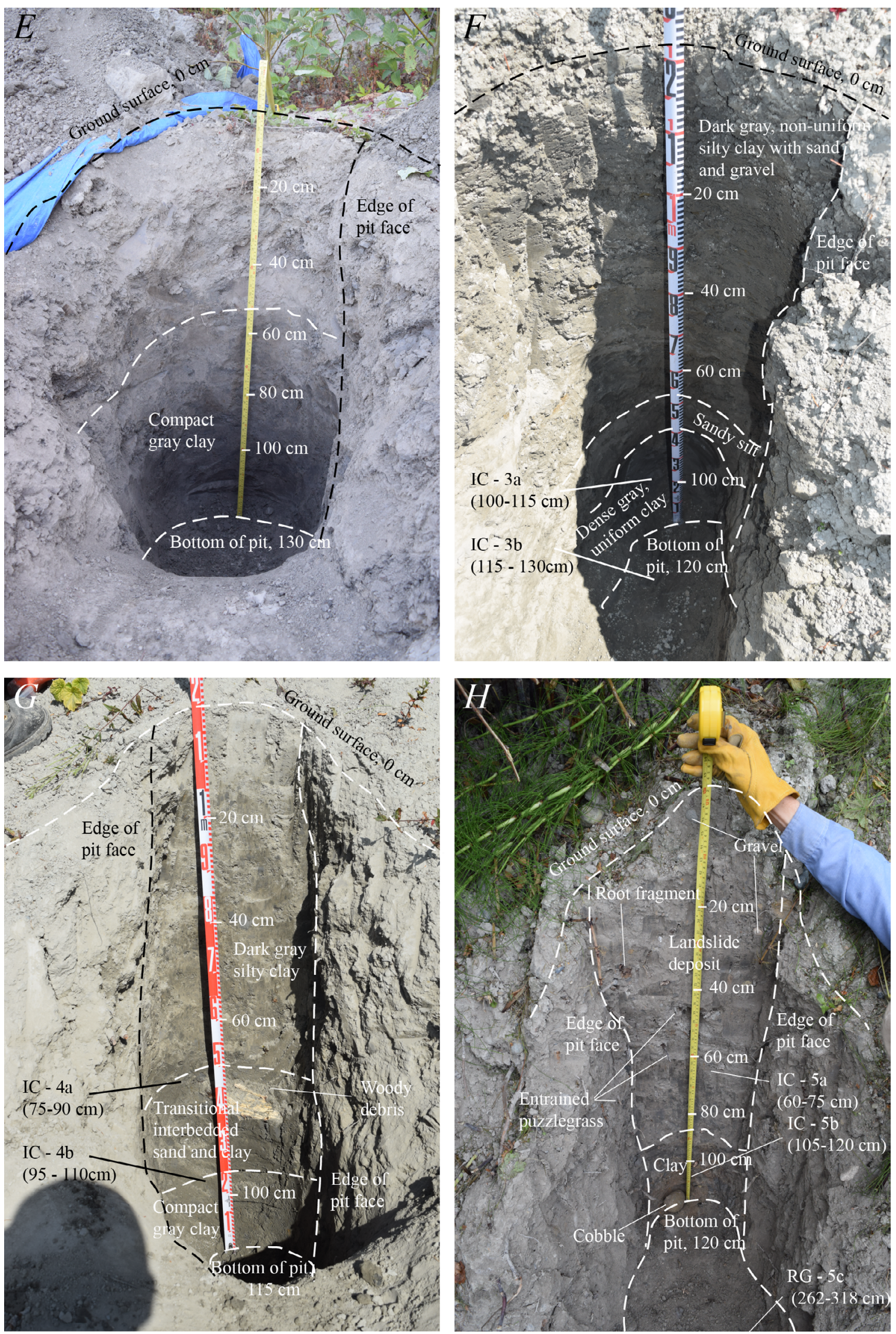

Figure 3.-Continued 
Figure 3 (previous pages). Photographs and descriptive logs of the LS site: $A$, exposure of glacial deposits on head scarp at location $1 ; B$, pit excavated at the base of the head scarp at location $1 ; C$, pit excavated in landslide deposits below the head scarp at location 1; $D$, exposure of glacial deposits on southern flank scarp at location 2; $E$, pit excavated at location 2 below the northern flank of the landslide; $F$, pit excavated in the landslide deposit at location 3; $G$, pit excavated in the landslide deposit at location 4; and $H$, pit excavated in the landslide deposit at location 5. Locations are shown on fig. $2 A$, instrumentation is summarized in table 4 , and specimen details are provided in table 5 (cm, centimeter).

\section{Vegetated Hillslope Site (VH)}

The VH site (figs. 1 and $2 B$ ) is also located on the City of Mukilteo property above the railway access line, approximately $0.6 \mathrm{~km}$ south of the LS site, and was accessed via a ROE agreement between the USGS, ST, the City of Mukilteo, and the adjacent HOA of One Club House Lane Sector 12. The residents of this neighborhood reported that while episodic slides occasionally block the railway corridor, there are also areas of active and ongoing slope instability along the coastal bluffs to the south of the site. Given the steep slope, similar geology to the LS site, and proximity to other unstable slopes, the VH site is potentially susceptible to slope failure. Surface morphology of the hillslope, including unevenly stepped topographic slopes and deformed trees, is consistent with past landslide activity.

The average slope of the bluff at the VH site is 35 degrees and the relief of the bluff above the railway line is $42 \mathrm{~m}$ (fig. $2 \mathrm{~B}$ ). Exposure of the sediments at the $\mathrm{VH}$ site is limited by dense vegetation and surface duff, but a steeply incised channel approximately $25 \mathrm{~m}$ to the north of the site (locally known as Hulk Creek) has exposed the underlying geology in a series of step pools and waterfalls (fig. 4A). The channel is incised 2 to $4 \mathrm{~m}$ through colluvium and into underlying glacial deposits, but because of steep channel walls and near-vertical waterfalls, only the lowermost step pool was safely accessible to observe directly. The step pools appear to correspond with dense horizontal planar features, though other fracture patterns and vertical linear or planar features in the channel walls are also apparent. Inspection of the channel walls in the lowermost step pool revealed that glacial deposits underlying the lower portion of the hillslope are composed of silty sandy hard gray till with highly deformed and folded linear or planar features (fig. $4 B$ ). 

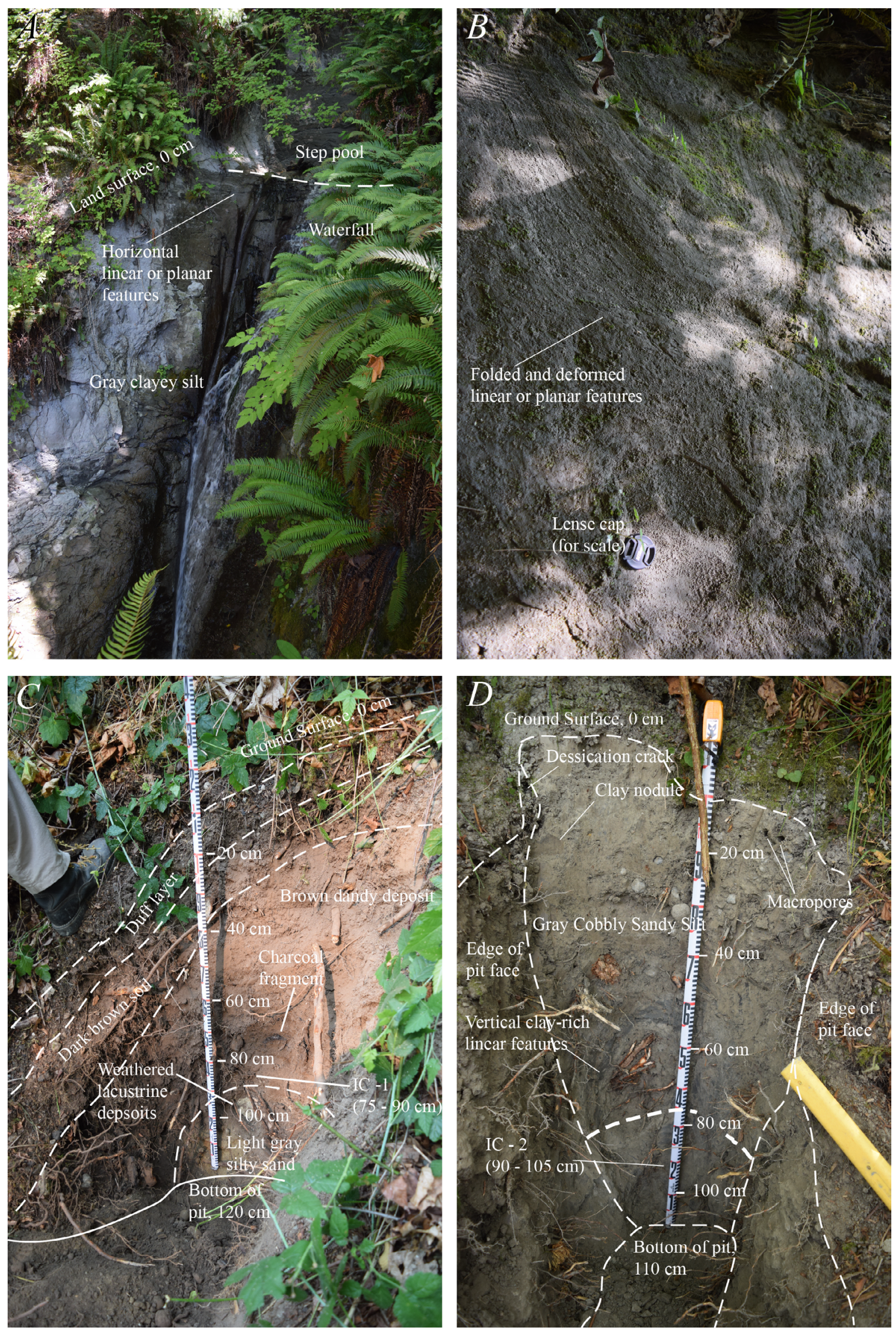

Figure 4. 

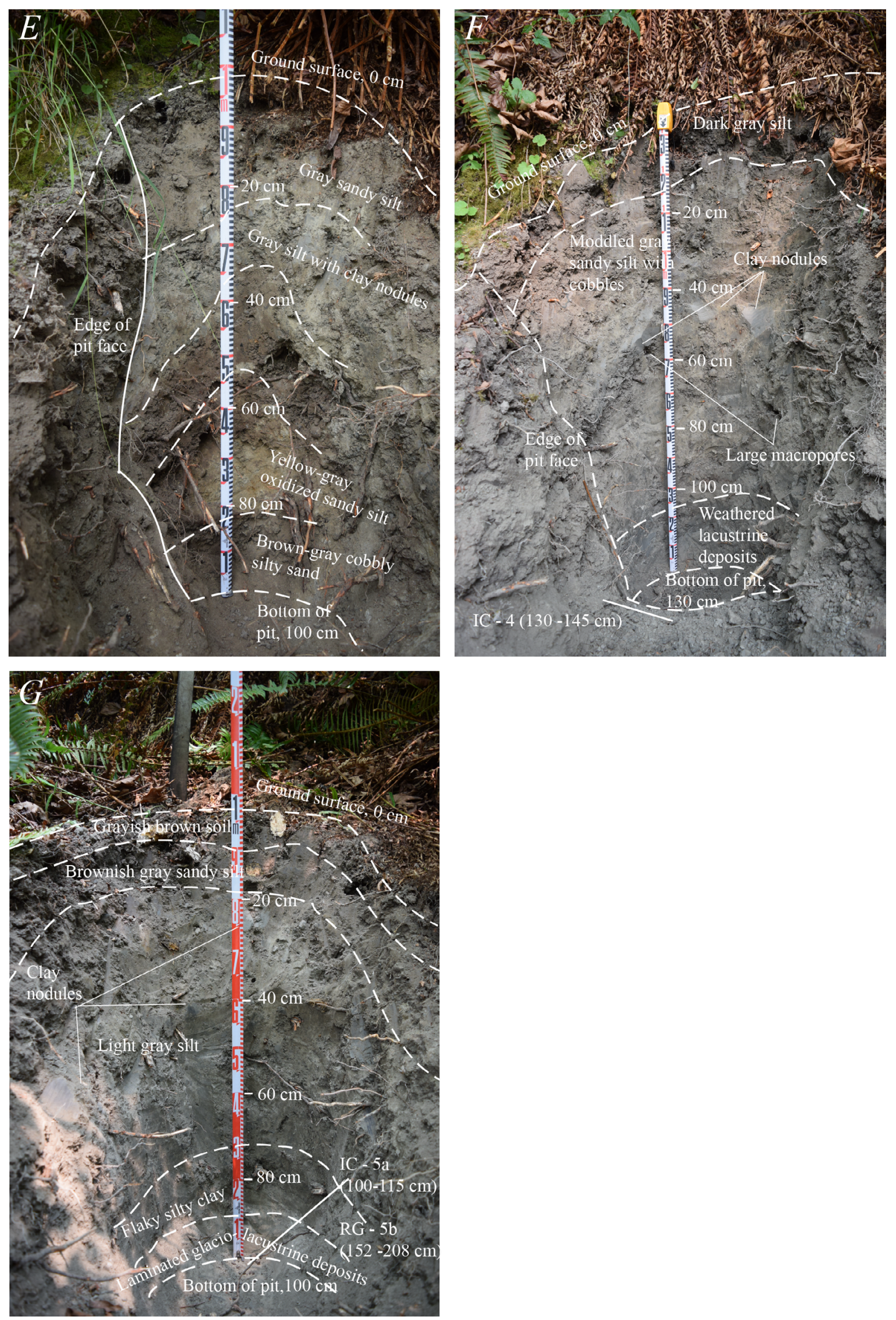

Figure 4.-Continued 
Figure 4 (previous pages). Photographs and descriptive logs of the VH site: $A$, exposure of in-situ glacial deposits along incised stream channel and step pool at approximate elevation of location $2 ; B$, detail of exposed glacial deposits in incised channel at approximate elevation of location $5 ; C$, pit excavated in colluvium at location $1 ; D$, pit excavated in colluvium at location $2 ; E$, pit excavated in colluvium at location $3 ; F$, pit excavated in colluvium at location 4; and $G$, pit excavated in colluvium at location 5 . Elevations of locations are shown on fig. $2 B$, instrumentation is summarized in table 4 , and specimen details are provided in table 5 (cm, centimeter).

\section{Profile Descriptions}

The stratigraphy was photographed for each pit excavated into the colluvium and for exposures of the underlying glacial deposits (figs. 3 and 4). Table 1 includes descriptions of the glacial deposit exposures at the LS site, table 2 includes descriptions of the landslide deposits revealed by excavated pits at the LS site, and table 3 includes descriptions of the colluvium deposits revealed by excavated pits at the VH site. Whereas the subsurface features revealed in the pits are described in terms of depth below the ground surface (tables 2 and 3), exposed features of the glacial deposits are described in terms of height above the base of each exposure (table 1). However, the stratigraphic profiles of both the excavated pits and exposures of glacial deposits are described from the top down, starting from the ground surface down to the bottom of the pit, or from the top of an exposure down to its base. Figures 3 and 4 also indicate the depth range of the intact core (IC) and repacked grab (RG) specimens of colluvium and glacial deposits that were collected for laboratory analysis (summarized in tables 4 and 5, and discussed in detail in the subsequent sections).

Table 1. Descriptive summary of glacial deposit exposures at the LS site.

\begin{tabular}{|c|c|c|}
\hline Location & $\begin{array}{l}\text { Height, above base of } \\
\text { exposure (centimeter) }\end{array}$ & Description \\
\hline \multirow[t]{5}{*}{ LS-1a } & & Main head scarp, exposure of glacial deposits (fig. $3 A$ ) \\
\hline & $475-485$ & Thin, organic-rich soil layer with abundant roots \\
\hline & $350-475$ & Sandy gravel outwash deposit with cobbles and sparse roots throughout \\
\hline & $145-350$ & $\begin{array}{l}\text { Gravel, cobble, and boulder rich outwash deposit with silty sand matrix, } \\
\text { roots absent }\end{array}$ \\
\hline & $0-145$ & $\begin{array}{l}\text { Light yellowish-gray silty clay with occasional gravel, cobbles, and } \\
\text { boulder clasts in place; extensive desiccation and (or) unloading } \\
\text { fractures; crusts of dried fine-grained sediments deposited over } \\
\text { portions of this exposure }\end{array}$ \\
\hline \multirow[t]{3}{*}{ LS-2a } & & Southern flank scarp, exposure of glacial deposits (fig. $3 D$ ) \\
\hline & $200-400$ & $\begin{array}{l}\text { Dense gray silty clay, heavily fractured (possibly from glacial unloading } \\
\text { or desiccation) }\end{array}$ \\
\hline & $0-200$ & $\begin{array}{l}\text { Gray silty sand with horizontal and vertical linear or planar features, } \\
\text { moderately fractured (possibly from glacial unloading) }\end{array}$ \\
\hline
\end{tabular}


Table 2. Descriptive summary of pits excavated into landslide deposits at the LS site.

\begin{tabular}{|c|c|c|}
\hline Location & Depth, below & Description \\
\hline \multirow[t]{3}{*}{ LS-1b } & & Upper pit, excavated failure surface at base of head scarp (fig. $3 B$ ) \\
\hline & $0-40$ & Light gray, nonuniform silty sand with gravel and cobbles throughout \\
\hline & $40-100$ & $\begin{array}{l}\text { Hard dark gray clayey siltstone, flakey with vertical and horizontal planar features, } \\
\text { with iron oxide weathering along linear or planar features }\end{array}$ \\
\hline \multirow[t]{6}{*}{ LS-1c } & & Lower pit, excavated landslide deposit below head scarp (fig. $3 C$ ) \\
\hline & $0-30$ & Dry cobbles, boulders, and gravel with silty sand matrix, some roots \\
\hline & $30-40$ & Gray, silty clay rich matrix, with moderate gravel and cobbles, some roots \\
\hline & $40-60$ & Dry cobbles, gravel, and boulders with sandy silt matrix \\
\hline & $60-70$ & Dense, wet, clay rich lens with woody debris \\
\hline & $70-100$ & Dense, wet dark gray clay matrix with cobbles and gravel \\
\hline \multirow[t]{3}{*}{ LS-2b } & & Pit excavated in deposits below northern flank scarp (fig. $3 E$ ) \\
\hline & $0-50$ & Light gray, nonuniform silty sand with gravel and cobbles throughout \\
\hline & $50-130$ & $\begin{array}{l}\text { Hard dark gray clayey silt deposit; wetter than overlying material with occasional } \\
\text { gravel and cobbles }\end{array}$ \\
\hline \multirow[t]{4}{*}{ LS-3 } & & Pit excavated in landslide deposits (fig. $3 F$ ) \\
\hline & $0-80$ & $\begin{array}{l}\text { Dark gray nonuniform silty clay with some sand and gravel; dislocations along } \\
\text { heterogeneities and structures }\end{array}$ \\
\hline & $80-90$ & Sandy silt layer (or large lens of this material, spanning width of pit) \\
\hline & $90-120$ & Hard, dark gray, uniform clay \\
\hline \multirow[t]{4}{*}{ LS-4 } & & Pit excavated in landslide deposits (fig. $3 G$ ) \\
\hline & $0-70$ & $\begin{array}{l}\text { Dark gray nonuniform silty clay with minor gravel and small amounts of sand; clay } \\
\text { inclusions within sandy clay matrix }\end{array}$ \\
\hline & $70-95$ & $\begin{array}{l}\text { Transition from silty clay with minor gravel to dense, dark gray, finely laminated } \\
\text { silty clay with minor sand }\end{array}$ \\
\hline & $95-110$ & $\begin{array}{l}\text { Very dense, plastic clay with trace amount of fine sand and coarse silt, fairly } \\
\text { uniform }\end{array}$ \\
\hline \multirow[t]{3}{*}{ LS-5 } & & Pit excavated in landslide deposits above toe of slope (fig. $3 H$ ) \\
\hline & $0-85$ & $\begin{array}{l}\text { Mottled silty/sandy deposit with numerous gravel inclusions, occasional cobbles } \\
\text { and boulders, numerous entrained root fragments and Equisetum (also known as } \\
\text { puzzlegrass or horsetail), grades from lighter more silt rich to darker, dense, } \\
\text { uniform clay }\end{array}$ \\
\hline & $85-120$ & Dense dark gray clay, with some cobbles and roots \\
\hline
\end{tabular}


Table 3. Descriptive summary of pits excavated into colluvium at the VH site.

\begin{tabular}{|c|c|c|}
\hline Location & Depth, below & Description \\
\hline \multirow[t]{6}{*}{ VH-1 } & & Pit excavated in colluvium (fig. $4 C$ ) \\
\hline & $0-10$ & Duff layer mixed with organic-rich sandy soil \\
\hline & $10-20$ & Brown sandy deposit with some soil development, numerous fine roots \\
\hline & $20-80$ & $\begin{array}{l}\text { Mottled brown sandy deposit with gravel and cobbles throughout, numerous roots; } \\
\text { in place sea shells, anthropogenic detritus (for example, golf ball) and charcoal } \\
\text { fragments suggest recent deposition and human activity }\end{array}$ \\
\hline & $80-100$ & $\begin{array}{l}\text { Loose, light gray dense, uniform silty sand, grades to underlying weathered glacial } \\
\text { deposits }\end{array}$ \\
\hline & $100-110$ & Weathered sandy glaciolacustrine deposits with platy structure \\
\hline \multirow[t]{5}{*}{ VH-2 } & & Pit excavated in colluvium (fig. $4 D$ ) \\
\hline & $0-1$ & Dry cobbles, boulders, and gravel with silty sand matrix, some roots \\
\hline & $1-3$ & Gray, silty clay rich matrix, with moderate gravel and cobbles, some roots \\
\hline & $3-80$ & Dry cobbles, gravel, and boulders with sandy silt matrix \\
\hline & $80-110$ & Dense, wet, clay rich lens with woody debris \\
\hline \multirow[t]{7}{*}{ VH-3 } & & Pit excavated in colluvium (fig. $4 E$ ) \\
\hline & $0-3$ & Fine root mat with gray silty material, desiccation cracks and minimal duff cover \\
\hline & $3-25$ & Uniform, gray sandy silt \\
\hline & $25-40$ & Gray sandy silty with large clay nodules and lenses \\
\hline & $40-50$ & Dark brown, organic-rich root zone of sandy silt \\
\hline & $50-80$ & Yellow-gray sandy silt with some red coloring (signs of oxidation and weathering) \\
\hline & $80-100$ & $\begin{array}{l}\text { Brown-gray sandy cobbly silty sand, possibly grading into gray glaciolacustrine } \\
\text { deposits }\end{array}$ \\
\hline \multirow[t]{6}{*}{ VH-4 } & & Pit excavated in colluvium (fig. $4 F$ ) \\
\hline & $0-1$ & Duff and mossy ground cover \\
\hline & $1-3$ & Fine root-mat from ferns, occasional desiccation cracks \\
\hline & $3-10$ & Dark gray organic-rich silt with some indications of soil formation \\
\hline & $10-105$ & $\begin{array}{l}\text { Mottled gray sandy silt with cobbles and interspersed throughout, some large } \\
\text { macropores }\end{array}$ \\
\hline & $105-130$ & Flakey, light-gray weathered, sandy silty glaciolacustrine deposits \\
\hline \multirow[t]{7}{*}{ VH-5 } & & Pit excavated in colluvium (fig. $4 G$ ) \\
\hline & $0-1$ & Duff cover \\
\hline & $1-10$ & $\begin{array}{l}\text { Dark grayish brown silty sand with some soil development; fine roots and } \\
\text { desiccation cracks }\end{array}$ \\
\hline & $10-20$ & $\begin{array}{l}\text { Very dense, plastic clay with trace amount of fine sand and coarse silt, fairly } \\
\text { uniform }\end{array}$ \\
\hline & $20-70$ & Brownish gray sandy silt with some roots \\
\hline & $70-90$ & Light gray silt with numerous clay nodules and occasional larger roots and cobbles \\
\hline & $90-100$ & Platy structured, laminated glaciolacustrine deposits \\
\hline
\end{tabular}




\section{Field Instrumentation}

The field-data collection system at each site consists of geotechnical and environmental sensors connected to data loggers equipped with a modem for cellular data transmission to computers hosted by both ST and the USGS. The equipment includes instrumentation to monitor rainfall, air temperature and pressure, and subsurface hydrologic response, which relate directly to factors affecting slope stability. Hydrological Services TB4 rain gages and air temperature sensors were installed at the LS and VH sites, as well as at two additional representative, nonvegetated locations farther north along the railway corridor (fig. 1), one at Mukilteo Lighthouse Park (M1) and another at the Mukilteo Water and Wastewater District's wastewater treatment plant (M2). The gages were placed with the purpose of collecting data to help investigate how interception by vegetation and throughfall (for example, Reid and Lewis, 2009) affect the spatial and temporal variability in rainfall that reaches the ground surface and can infiltrate.

Subsurface hydrologic monitoring instruments were installed in soil pits at both LS and VH sites and also within the head scarp at the LS site. The hydrologic instruments include Decagon EC-5 sensors to measure volumetric water content, Umwelt-Monitoring-Systeme (UMS) T-8 tensiometers to measure variably saturated pore pressures, and standpipe piezometers with Slope Indicator vibrating-wire pressure sensors to measure shallow water-table fluctuations. Increases in the quantity and pressure of subsurface water contribute to occurrence of most landslides that affect the rail corridor, and this array of sensors was selected to detect the temporal dynamics of these water conditions in the shallow subsurface. Each location at the VH includes two instruments, one water-content sensor and either one tensiometer or one piezometer. Each location at the LS site includes two pairs of instruments, nested at shallower and deeper positions within the subsurface. Thus, each LS instrumented location includes two volumetric water content sensors, and either two tensioimeters or two piezometers. A summary of the number and type of instruments placed at the five locations for each site is provided in table 4.

Table 4. Summary of instrumentation and specimen collection for each site location (see figs. 1 and 2).

\begin{tabular}{|c|c|c|c|c|c|c|}
\hline Site location & $\begin{array}{l}\text { Rain } \\
\text { gages }\end{array}$ & $\begin{array}{c}\text { Air } \\
\text { temperature } \\
\text { sensors }\end{array}$ & $\begin{array}{l}\text { Piezo- } \\
\text { meters }\end{array}$ & $\begin{array}{l}\text { Tensio- } \\
\text { meters }\end{array}$ & $\begin{array}{l}\text { Water- } \\
\text { content } \\
\text { sensors }\end{array}$ & $\begin{array}{c}\text { Total } \\
\text { specimens } \\
\text { collected }\end{array}$ \\
\hline Landslide (LS) & 1 & 1 & & & & \\
\hline 1 & & & 2 & 0 & 2 & 1 \\
\hline 2 & & & 0 & 2 & 2 & 1 \\
\hline 3 & & & 0 & 2 & 2 & 2 \\
\hline 4 & & & 0 & 2 & 2 & 2 \\
\hline 5 & & & 2 & 0 & 2 & 3 \\
\hline Vegetated hillslope (VH) & 1 & 1 & & & & \\
\hline 1 & & & 1 & 0 & 1 & 1 \\
\hline 2 & & & 0 & 1 & 1 & 1 \\
\hline 3 & & & 0 & 1 & 1 & 1 \\
\hline 4 & & & 0 & 1 & 1 & 1 \\
\hline 5 & & & 1 & 0 & 1 & 3 \\
\hline Mukilteo Lighthouse Park (M1) & 1 & 1 & & & & \\
\hline $\begin{array}{l}\text { Mukilteo Water and Wastewater District treatment } \\
\text { plant (M2) }\end{array}$ & 1 & 1 & & & & \\
\hline
\end{tabular}




\section{Laboratory Analyses of Colluvium and Glacial Sediments}

Laboratory analyses of colluvium and glacial sediment specimens from both the LS and VH sites were conducted at the Colorado School of Mines in Golden, Colorado, and at Cooper Testing Labs Inc., in Palo Alto, California. These laboratory analyses were to quantify the physical, hydraulic, and material properties of the subsurface materials; testing was performed according to ASTM International standard methods whenever applicable (ASTM reference numbers or appropriate citations provided for each type of analysis). The specimens included intact cores (IC) of the colluvium collected from selected pits and sealed to preserve in situ moisture content, as well as repacked grab specimens (RG) of the glacial sediments extracted from deeper boreholes during hand auguring. Due to the methodology and destructive nature of certain laboratory analyses it was not possible to conduct the same analyses on each of the specimens. Instead, a combination of different analyses on different specimens was selected to provide representative characterization of the colluvium and deeper glacial deposits at both sites.

A summary of the collection depths and physical properties of each specimen is shown in table 5. Physical properties measured included specific gravity (ASTM D854), total porosity (ASTM D7263), bulk and grain densities (ASTM D854 and D2937), grain-size distribution (ASTM D422), and in situ volumetric water content (ASTM D2216). Additionally, both liquid and plastic limits were estimated with the wet preparation method (ASTM D4318). Hydraulic properties were evaluated using falling head permeameter tests to measure saturated hydraulic conductivity (ASTM D5084), and the Transient Water Release and Imbibitions Method (TRIM) (Wayllace and Lu, 2012) to estimate water-retention characteristic curves. A summary of the hydraulic and material properties of selected specimens are provided in tables 6 and 7. Geotechnical properties were determined with a combination of triaxial compression tests (ASTM D4767) to estimate soil strength, and torsional ring shear tests (ASTM D6467) for residual strength. A summary of these strength properties is provided in table 9 .

The TRIM method for estimating unsaturated hydraulic properties was applied to four specimens from the VH site collected in soil pits 1,2, 3, and 5 (table 7). Triaxial compression tests were performed on two intact cores from the LS site collected at different depths in soil pit 3 (specimens $3 \mathrm{a}$ and $3 \mathrm{~b}$, see table 5), and pore pressures were monitored in these consolidated-undrained specimens during three stages of loading, with the strength values reported (table 9) derived using effective stress conditions. For the shallower specimen (LS 3a) pressures of 2.8, 5.4, and 10.9 kilopascals (kPa) were applied, and for the deeper specimen (LS 3b) pressures of 7.3, 21.8, and $43.5 \mathrm{kPa}$ were applied. Torsion residual shear tests were conducted on two fully softened repacked grab specimens of the glacial deposits from each site (LS 5c and VH 5b) under three stages of loading at 40, 80, and $160 \mathrm{kPa}$. The direct shear tests were conducted on four intact specimens from the VH site, and for all four specimens (VH 1, 3, 4, and 5 ), the three stages of pressure applied were 25,50 , and $100 \mathrm{kPa}$. Laboratory testing data results are available from the USGS ScienceBase (Mirus and others, 2016). 
Table 5. Summary of specimen collection location and depth, geologic material, physical descriptions, laboratory testing facility, and corresponding figure.

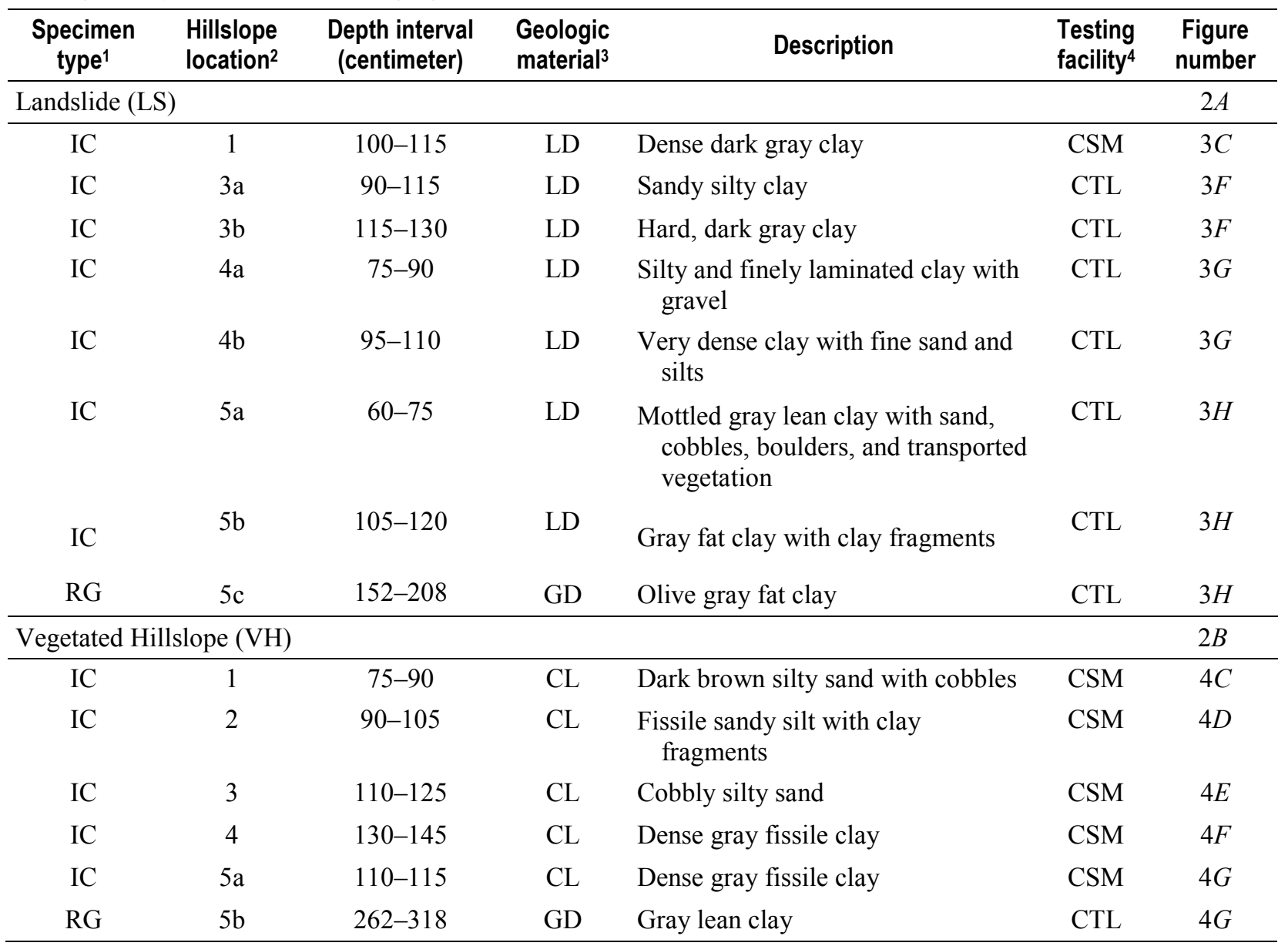

${ }^{1} \mathrm{IC}$, Intact core specimen (undisturbed); RG, repacked grab specimen of auger cuttings (disturbed).

${ }^{2}$ See fig. 2 for hillslope position numbers; a, Shallow; b, Middle; c, Deep.

${ }^{3}$ LD, Landslide Deposit; GD, Glacial Deposit; CL, Colluvium.

${ }^{4} \mathrm{CSM}$, Colorado School of Mines; CTL, Cooper Testing Laboratory, Inc. 
Table 6. Summary of particle size distributions and physical properties of selected specimens. $\left[\mathrm{g} / \mathrm{cm}^{3}\right.$, grams per cubic centimeter; \%, percent $]$

\begin{tabular}{ccccccccc}
\hline Specimen & $\begin{array}{c}\text { Specific } \\
\text { gravity (-) }\end{array}$ & $\begin{array}{c}\text { Bulk density, } \\
\text { wet }\left(\mathbf{g} / \mathbf{c m}^{3}\right)\end{array}$ & $\begin{array}{c}\text { Bulk density, } \\
\text { dry }\left(\mathbf{g} / \mathbf{c m}^{3}\right)\end{array}$ & $\begin{array}{c}\text { USCS } \\
\text { class }^{2}\end{array}$ & $\begin{array}{c}\text { Gravel } \\
(\%)\end{array}$ & $\begin{array}{c}\text { Sand } \\
(\%)\end{array}$ & $\begin{array}{c}\text { Silt } \\
(\%)\end{array}$ & $\begin{array}{c}\text { Clay } \\
(\%)\end{array}$ \\
\hline Landslide (LS) & & & & & & & & \\
\hline IC-3a & 2.78 & $\mathrm{NM}^{3}$ & 1.43 & $\mathrm{CH}$ & 2.1 & 9.1 & 73.1 & 15.7 \\
IC-3b & 2.79 & $\mathrm{NM}^{3}$ & 1.40 & $\mathrm{CH}$ & 0 & 0.5 & 34.9 & 64.6 \\
IC-4a & 2.77 & 1.89 & 1.50 & $\mathrm{CL}$ & 0 & 10.9 & 76.3 & 12.8 \\
IC-4b & 2.81 & 1.85 & 1.38 & $\mathrm{CH}$ & 0.3 & 4.5 & 53.6 & 41.6 \\
IC-5a & 2.79 & 1.79 & 1.51 & $\mathrm{CL}$ & 6.2 & 19.0 & 56.1 & 18.7 \\
IC-5b & 2.79 & 1.76 & 1.38 & $\mathrm{CH}$ & 2.2 & 10.4 & 54.0 & 33.4 \\
\hline
\end{tabular}

${ }^{1}$ See table 5 for specimen collection and analyses details.

${ }^{2}$ USCS, Unified Soil Classification System; C, Clay; H, High plasticity; L, Low plasticity.

${ }^{3} \mathrm{NM}$, not measured.

Table 7. Hydraulic properties and plasticity of selected specimens.

[cm/s, centimeters per second; \%, percent]

\begin{tabular}{ccccccc}
\hline Specimen & $\begin{array}{c}\text { Ksat } \\
(\mathbf{c m} / \mathbf{s})^{2}\end{array}$ & $\begin{array}{c}\text { Porosity } \\
(\%)\end{array}$ & $\begin{array}{c}\text { Volumetric water } \\
\text { content } \\
(\%)^{3}\end{array}$ & $\begin{array}{c}\text { Liquid } \\
\text { limit }\end{array}$ & $\begin{array}{c}\text { Plastic } \\
\text { limit }\end{array}$ & $\begin{array}{c}\text { Plasticity } \\
\text { index }\end{array}$ \\
\hline Landslide (LS) & & & & & & \\
\hline IC-1 & $\mathrm{NM}^{7}$ & $\mathrm{NM}$ & 26.1 & $\mathrm{NM}$ & $\mathrm{NM}$ & $\mathrm{NM}$ \\
IC-3a & $\mathrm{NM}$ & 33.9 & 25.3 & 79 & 35 & 44 \\
IC-3b & $\mathrm{NM}$ & 35.6 & 32.5 & 64 & 28 & 36 \\
IC-4a & $4.0 \times 10^{-7}$ & 46.1 & 39.7 & 43 & 24 & 19 \\
IC-4b & $7.0 \times 10^{-8}$ & 50.8 & 46.6 & 53 & 27 & 23 \\
IC-5a & $7.0 \times 10^{-6}$ & 45.7 & 28.1 & 38 & 21 & 17 \\
IC-5b & $3.0 \times 10^{-5}$ & 50.5 & 38.4 & 50 & 24 & 26 \\
RG-5c & NM & NM & NM & 59 & 28 & 31 \\
\hline Vegetated Hillslope $(\mathrm{VH})$ & & & & & & \\
\hline IC-1 & Table $8^{5}$ & Table $8^{5}$ & 8.9 & Non plastic (sandy) & \\
IC-3 & Table $8^{5}$ & Table $8^{5}$ & 11.1 & 23 & 19 & 4 \\
IC-4 & Table $8^{5}$ & Table $8^{5}$ & 15.3 & 32 & 21 & 10 \\
IC-5a & Table $8^{5}$ & Table $8^{5}$ & 24.0 & 43 & 23 & 20 \\
RG-5b & NM & NM & NM & 41 & 22 & 19 \\
\hline
\end{tabular}

${ }^{1}$ See fig. 2 and table 5.

${ }^{2} \mathrm{~K}_{\text {sat }}$, Saturated hydraulic conductivity.

${ }^{3}$ Volumetric water content during specimen collection in July 2015.

${ }^{4}$ Weight of soil solids relative to weight of an equal volume of water.

${ }^{5}$ Values of saturated hydraulic conductivity and saturated volumetric water content during wetting and drying conditions are provided in table 8 .

${ }^{6}$ Liquid and plastic limits, and plasticity cannot be determined for sandy specimens.

${ }^{7} \mathrm{NM}$, not measured. 
Table 8. Unsaturated hydraulic properties determined using the Transient Water Release and Imbibitions Method (TRIM) for selected specimens.

[kPa, kilopascals; $\mathrm{cm} / \mathrm{s}$, centimeters per second]

\begin{tabular}{|c|c|c|c|c|c|c|c|c|c|c|}
\hline Specimen $^{1}$ & & & Wetting & & & & & Drying & & \\
\hline VH & $\alpha(1 / \mathrm{kPa})^{2}$ & $n(-)^{2}$ & $\theta_{s}(-)^{2}$ & $\theta_{r}(-)^{2}$ & $K_{\text {sat }}(\mathrm{cm} / \mathrm{s})^{2}$ & $\alpha(1 / \mathrm{kPa})^{2}$ & $n(-)^{2}$ & $\theta_{s}(-)^{2}$ & $\theta_{r}(-)^{2}$ & $K_{\text {sat }}(\mathrm{cm} / \mathrm{s})^{2}$ \\
\hline IC-1 & 0.23 & 1.52 & 0.54 & 0.04 & $1.08 \times 10^{-3}$ & 0.73 & 1.52 & 0.38 & 0.04 & $1.80 \times 10^{-3}$ \\
\hline IC-3 & 0.30 & 1.34 & 0.51 & 0.14 & $8.51 \times 10^{-4}$ & 0.6 & 1.34 & 0.36 & 0.14 & $8.51 \times 10^{-4}$ \\
\hline IC-4 & 0.14 & 1.47 & 0.59 & 0.24 & $3.90 \times 10^{-4}$ & 0.29 & 1.43 & 0.45 & 0.24 & $3.90 \times 10^{-4}$ \\
\hline IC-5a & 0.44 & 1.53 & 0.61 & 0.14 & $7.49 \times 10^{-4}$ & 2.14 & 1.47 & 0.36 & 0.14 & $7.49 \times 10^{-4}$ \\
\hline
\end{tabular}

${ }^{1}$ See fig. 2 and table 5.

${ }^{2} \alpha$, van Genuchten (1980) air entry parameter; $n$, van Genuchten (1980) water retention shape factor parameter; $\theta_{s}$, saturated volumetric water content; $\theta_{r}$, residual volumetric water content; $K_{\text {sat }}$, saturated hydraulic conductivity.

Table 9. Material strength properties of selected specimens.

$\left[\mathrm{kPa}\right.$, kilopascals; ${ }^{\circ}$, degrees]

\begin{tabular}{ccccc}
\hline Specimen ${ }^{1}$ & $\begin{array}{c}\text { Cohesion, } \\
\text { peak (kPa) }\end{array}$ & $\begin{array}{c}\text { Cohesion, } \\
\text { residual (kPa) }\end{array}$ & $\begin{array}{c}\text { Angle of friction, } \\
\text { peak }\left({ }^{\circ}\right)\end{array}$ & $\begin{array}{c}\text { Angle of friction, } \\
\text { residual }\left({ }^{\circ}\right)\end{array}$ \\
\hline IC-3a & $\mathrm{NM}^{2}$ & 0 & $\mathrm{NM}$ & 36.5 \\
IC-3b & $\mathrm{NM}$ & 16.8 & $\mathrm{NM}$ & 29.1 \\
RG-5c & $\mathrm{NM}$ & 0 & $\mathrm{NM}$ & 23.0 \\
\hline IC-1 & 1.64 & $\mathrm{NM}$ & 22.02 & $\mathrm{NM}$ \\
IC-3 & 1.57 & $\mathrm{NM}$ & 19.93 & $\mathrm{NM}$ \\
IC-4 & 0.59 & $\mathrm{NM}$ & 21.30 & $\mathrm{NM}$ \\
IC-5a & 4.80 & $\mathrm{NM}$ & 28.72 & $\mathrm{NM}$ \\
RG-5b & $\mathrm{NM}$ & 0 & $\mathrm{NM}$ & 30.0 \\
\hline
\end{tabular}

${ }^{1}$ See fig. 2 and table 5 .

${ }^{2} \mathrm{NM}$, Not measured.

Note: testing methods to determine strength properties vary based on specimen types and laboratory facility (see table 5), so not all properties were determined for all specimens.

\section{Discussion}

\section{Advances in Monitoring and Characterization}

Prior USGS research efforts along the Seattle-Everett railway corridor include hydrologic monitoring of similar coastal bluffs in Everett and Edmonds (Baum and others, 2005b), which led to direct observations of the rainfall and hydrologic response conditions leading up to the failure of a vegetated hillslope (Godt and others, 2009). Similarly, the present study includes characterization and instrumentation of a densely vegetated hillslope that remained stable during this study, but is likely prone to failure (that is, the VH site). However, this study also includes monitoring of a recent landslide (LS), in an effort to improve understanding of the rainfall and hydrologic response conditions that may 
cause reactivation of recent slides as compared to the conditions necessary to destabilize a densely vegetated hillslope.

Subsurface monitoring at the Edmonds site consisted of hourly measurements of volumetric water content at eight depths and pore pressures at six depths, whereas at the Everett site only volumetric water content was measured, but at three depths within a soil profile (Baum and others, 2005b). Relative to these previous efforts along Puget Sound, installations at the LS and VH sites in Mukilteo (figs. 1 and 2, table 4) incorporate subsurface sensors for monitoring a greater number of hillslope locations at each site (five as opposed to one or two), which allows a more comprehensive assessment of downslope variations in water flow and pore-pressure changes. The sites instrumented for the present study also each include piezometers to measure shallow water-table fluctuations near both the top of the bluff and the toe of the slope (fig. 2). The present study uses similar tipping-bucket rain gages as were installed at the Everett and Edmonds sites, but also includes additional rain gage sites to quantify spatial variability of rainfall along the coastal bluffs above Puget Sound (fig. 1). Another similarity between earlier efforts and the installations described in this report is the use of telemetry to allow near-real-time uploads of data to the USGS and ST computers by cellular networks. The rainfall at the LS, VH, M1, and M2 sites and hydrologic-response measurements at the LS and VH sites are uploaded hourly and posted on the USGS Landslide Hazards Program Web site (http://landslides.usgs.gov/monitoring/seattle/rtd/bluff_hydrology.php).

Characterization of the hydraulic properties at the Edmonds and Everett sites included direct in situ measurements of saturated hydraulic conductivity using a permeameter and estimates of waterretention curves using capillary-rise tests on remixed colluvium (Godt and McKenna, 2008). Godt and McKenna (2008) also measured the strength parameters of two representative specimens of repacked colluvium mixtures using direct shear tests. In the present study, saturated hydraulic conductivity and unsaturated hydraulic properties of undisturbed core specimens of colluvium were measured in the laboratory under wetting and drying conditions (tables 6 and 7). Furthermore, strength parameters of both intact core specimens of the colluvium and repacked glacial deposits were measured in the laboratory using a combination of direct shear, torsional shear, and triaxial compression tests (table 9).

\section{Representativeness of Monitoring Sites}

Given the lack of detailed geologic mapping of the contact between the Whidbey Formation and the underlying Double Bluff Drift, combined with the lack of accessible outcrops at the LS and VH sites, it remains difficult to confirm which of these two formations (or both) underlies the monitoring sites without constraints on geologic ages. Although the uppermost lodgement till of the Double Bluff Drift was not present in the head scarp at the LS site or visible in the incised channel near the VH site, observations of vertical lineations as well as silts, clays, and sands with pebbles and gravel are consistent with previous characterization of the upper sections of the Double Bluff Drift (Minard, 1983). However, observations of highly deformed lineations (fig. $4 B$ ) and oxidization within the silty and sandy units (fig. 3A) are consistent with descriptions of the Whidbey Formation (Minard, 1983). Additionally, the stratigraphic sequence of outwash gravel, overlying silt and clay, overlying fine sand, observed at the head scarp at the LS site is consistent with type sections of the lower Whidbey Formation (Booth and others, 2003). Both formations are known to be thick, highly heterogeneous glacial deposits that, when exposed along the coastal bluffs, are prone to failure following sustained and (or) intense rainfall as infiltration leads to elevated pore pressures. Slope failures in the Double Bluff Drift are believed to occur along vertical partings (Minard, 1983), which were observed at the LS site, and failures within the Whidbey Formation are believed to occur at exposed contacts between units of sand and clay (Minard, 1983), which were also observed at the LS site. Additionally, these linear 
partings appear to exert structural controls on formation of step pools in a small channel to the north of the $\mathrm{VH}$ instrumentation (fig. $4 A$ ). Despite uncertainty about the precise geologic formation and age of the glacial deposits at the monitoring sites, the general topographic characteristics of the bluffs and stratigraphy of the glacial deposits are consistent with other landslide-prone bluffs along Puget Sound (Schulz, 2007).

Visual inspection of the colluvium deposits at the two sites suggests that the LS colluvium is composed largely of well-mixed, fine-grained landslide deposits with limited organic matter. Whereas the VH site is overlain by a more heterogeneous layer of sandy, more organic-rich colluvium or soil, that seems to grade downslope into finer grained silty clay. Laboratory analysis confirms the difference in average grain size and reveals some further contrasts in physical and hydraulic properties between the two sites. The unconsolidated colluvium specimens collected at several locations at the VH site are considerably sandier than the dense, clay-rich colluvium collected at the LS site (table 5). The colluvium specimens collected at the LS site are considerably less permeable than the VH colluvium (table 6), which reflects the difference in the formation and depositional setting of the vegetated hillslope at the VH site compared with recent and active landslide deposits at the LS site. Despite these variations between the two sites, the colluvium at both sites is generally fine-grained, rich in clays, and highly plastic (tables 6 and 7), which is consistent with other landslide-prone colluvium and glacial deposits along the coastal bluffs in the region.

Previous measurements of geotechnical properties for glacial deposits in the Greater Seattle area (Savage and others, 2000b, Godt and McKenna, 2008) provide a useful benchmark for evaluating the properties obtained from specimens collected at the LS and VH sites in Mukilteo to determine their representativeness for conditions along the rest of the railway corridor. Savage and others (2000b) provide a summary of prior studies focused mainly on the Whidbey Formation and the younger, overlying deposits. Furthermore, Godt and McKenna (2008) present results from direct laboratory test results on the Vashon advance outwash deposits and the Lawton Clay Member of the Vashon Drift. However, neither of these previous studies includes information on the older Double Bluff Drift. Regardless, comparison of laboratory analyses from the present study with these previously published material and hydraulic properties (fig. 5) illustrates that the colluvium specimens analyzed from both the LS and VH sites are largely consistent with the range of values reported for similar, yet somewhat younger glacial deposits. Values for saturated hydraulic conductivities at the VH site are at least an order of magnitude higher than at all the other locations, and one specimen from the LS site displays a somewhat higher internal angle of friction than the remaining sites (fig. 5). Otherwise the two study locations appear to exhibit properties that are representative of conditions elsewhere along the rail corridor. 

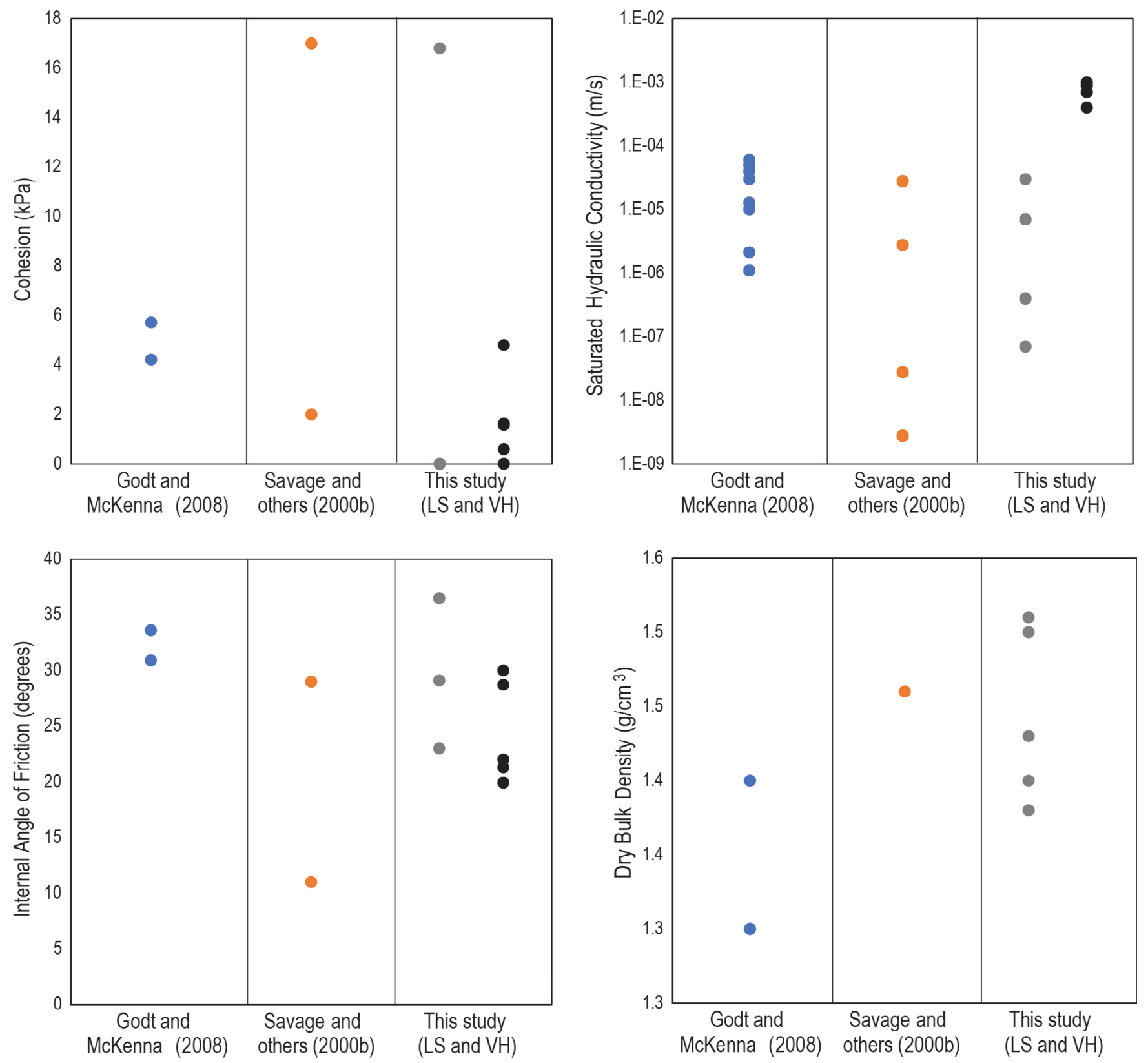

Figure 5. Cohesion, internal angle of friction, saturated hydraulic conductivity, and bulk density values reported for other similarly aged glacial deposits in Everett and Seattle (Godt and McKenna, 2008; Savage and others, 2000b) compared to laboratory measurements conducted on specimens from this study. Results for specimens from this study are shown in lighter gray on the left hand side for the LS and in darker gray circles on the right hand side for the VH site. 


\section{Summary}

This report describes work completed by the U.S. Geological Survey (USGS) during the summer 2015 as part of a specific cooperative effort with Sound Transit (ST) to monitor hydrologic conditions at two sites in Mukilteo, Washington, and subsequently to assess shallow landslide potential along the extent of the railway corridor between Seattle and Everett, Washington. The installations in Mukilteo build on findings from previous USGS monitoring along the Puget Sound Railway corridor and were designed to improve understanding of linkages between rainfall thresholds and subsurface hydrologic response processes leading to landslide initiation. Relative to previous monitoring, the installations presented here involve denser arrays of soil moisture and pore pressure sensors and additional rain gages along the railway corridor; the installations also measure shallow water-table fluctuations. The near-real-time observations of rainfall and hydrologic response for the sites in Mukilteo were designed to be used by ST to inform the development of a landslide early warning system for the rail corridor along the eastern shore of Puget Sound.

The hydrologic monitoring data will also be used in conjunction with the detailed site characterization to investigate the controls on landslide initiation thresholds using physical models of bluff hydrology and slope stability. Direct observations from soil pits and laboratory analyses of specimens collected confirm that the material and hydraulic properties at the selected sites are consistent with previously reported properties for similar glacial deposits and colluvium across the Greater Seattle area. Site-specific measurements for the Landslide site (LS) and Vegetated Hillslope site (VH) specimens will provide more accurate parameterization of hydrologic and slope-stability models; moreover, the observed properties will be useful for examining a wider variety of possible conditions along the coastal bluffs of Puget Sound. The colluvium deposits at the LS site have a greater clay content and plasticity, but lower saturated hydraulic conductivity relative to the colluvium deposits at the VH site. These distinct differences between the two sites may help explain why the LS site has failed recently, whereas the VH site has been stable in recent years. Furthermore, the dense, clay-rich unit near the head scarp of the LS site is similar to lower permeability units within the Whidbey Formation and the Double Bluff Drift, which can lead to perched saturation and contribute to slope failures. Overall, the two sites present useful end-members that are representative of the possible conditions for stable and unstable coastal bluffs along the Puget Sound railway.

\section{References}

Allstadt, K., Vidale, J.E., and Frankel, A.D., 2013, A scenario study of seismically induced landsliding in Seattle using broadband synthetic seismograms: Bulletin of the Seismological Society of America, v. 103, no. 6, p. 2971-2992.

Baum, R.L., and Godt, J.W., 2010, Early warning of rainfall-induced shallow landslides and debris flows in the USA: Landslides, v. 7 p., 259-272. doi10.1007/s10346.

Baum, R.L., Chleborad, A.F., and Schuster, R.L., 1998, Landslides triggered by the December 1996 and January 1997 storms in the Puget Sound area, Washington: U.S. Geological Survey Open-File Report 98-239, 16 p., available at http://pubs.usgs.gov/of/1998/ofr-98-239/.

Baum, R.L., Harp, E.L., and Hultman, W.A., 2000, Map showing recent and historic landslide activity on coastal bluffs of Puget Sound between Shilshole Bay and Everett, Washington: U.S. Geological Survey Miscellaneous Field Studies Map, MF 2346, 1 sheet, 1:24,000, available at http://pubs.usgs.gov/mf/2000/mf-2346/. 
Baum, R.L., Coe, J.A., Godt, J.W., Harp, E.L., Reid, M.E., Savage, W.Z., Schulz, W.H., Brien, D.L., Chleborad, A.F., McKenna, J.P., and Michael, J.A., 2005a, Regional landslide-hazard assessment for Seattle, Washington, USA: Landslides, v. 2, no. 4, p. 266-279, doi: 10.1007/s10346-005-0023-y. Baum, R.L., McKenna, J.P., Godt, J.W., Harp, E.L., and McMullen, S.R., 2005b, Hydrologic monitoring of landslide-prone coastal bluffs near Edmonds and Everett, Washington, 2001-2004: U.S. Geological Survey Open-File Report 2005-1063, 42 p.

Baum, R.L., Savage, W.Z., and Godt, J.W., 2008, TRIGRS-A FORTRAN program for transient rainfall infiltration and grid-based regional slope-stability analysis, Version 2.0: U.S. Geological Survey Open-File Report 2008-1159, 75 p.

Baum, R.L., Godt, J.W., and Savage, W.Z., 2010, Estimating the timing and location of shallow rainfall-induced landslides using a model for transient, unsaturated infiltration: Journal of Geophysical Research, Earth Surface, v. 115, F03013, doi:10.1029/2009JF001321.

Booth, D.B., Troost, K.G., Clague, J.J., and Waitt, R.B., 2003, The cordilleran ice sheet, in Gillespie, A.R., Porter, S.C., and Atwater, B.F., eds., Development in Quaternary science, volume 1-The Quaternary period in the United States: Elsevier, ISSN 1571-0866, v. 1, p. 17-43, doi:10.1016/S15710866(03)01002-9.

Brien, D.L., and Reid, M.E., 2008, Assessing deep-seated landslide susceptibility using 3-D groundwater and slope-stability analyses, southwestern Seattle, Washington, in Baum, R.L., Godt, J.W., and Highland, L.M., eds., Landslides and engineering geology of the Seattle, Washington, area: Geological Society of America Reviews in Engineering Geology, v. XX, p. 83-101, doi:10.1130/2008.4020(05).

Chleborad, A.F., 2000, A method for anticipating the occurrence of precipitation-induced landslides in Seattle, Washington: U.S. Geological Survey Open-File Report 2000-469, 29 p.

Chleborad A.F., 2003, Preliminary evaluation of a precipitation threshold for anticipating the occurrence of landslides in the Seattle, Washington, area: U.S. Geological Survey Open-File Report 2003-463, 39 p.

Chleborad, A.F. Baum, R.L., and Godt, J.W., 2006, Rainfall thresholds for forecasting landslides in the Seattle, Washington, area-Exceedance and probability: U.S. Geological Survey Open-File Report 2006-1064, 35 p.

Chleborad, A.F., Baum, R.L., and Godt, J.W., 2008, A prototype system for forecasting landslides in the Seattle, Washington, area in Baum, R.L., Godt, J.W., and Highland, L.M., eds., Engineering geology and landslides of the Seattle, Washington, area: Geological Society of America Reviews in Engineering Geology v. XX, p. 103-120, doi:10.1130/2008.4020(06).

Coe, J.A., Michael, J.A., Crovelli, R.A., and Savage, W.Z., Laprade, W.T., and Nashem, W.D., 2004, Probabilistic assessment of precipitation-triggered landslides using historical records of landslide occurrence, Seattle, Washington: Environmental \& Engineering Geoscience, v. 10, p. 103-122.

Godt, J.W., Baum, R.L., and Chleborad, A.F., 2006, Rainfall characteristics for shallow landsliding in Seattle, Washington, USA: Earth Surface Processes and Landforms, v. 31, p. 97-110.

Godt, J.W., and McKenna, J.P., 2008, Hydrological response of hillside materials to infiltration: Implications for shallow landsliding in the Seattle area, in Baum, R.L., Godt, J.W., and Highland, L.M., eds., Landslides and engineering geology of the Seattle, Washington, area: Geological Society of America Reviews in Engineering Geology, v. XX, p. 121-135.

Godt, J.W., Schulz, W.H., Baum, R.L., and Savage, W.Z., 2008a, Modeling rainfall conditions for shallow landsliding in Seattle, Washington, in Baum, R.L., Godt, J.W., and Highland, L.M., eds., Landslides and engineering geology of the Seattle, Washington area: Geological Society of America Reviews in Engineering Geology, v. XX, p. 137-152, doi: 10.1130/2008.4020(08). 
Godt, J.W., Baum, R.L., Savage, W.Z., Salciarini, Diana, Schulz, W.H., and Harp, E.L., 2008b, Transient deterministic shallow landslide modeling - Requirements for susceptibility and hazard assessments in a GIS framework: Engineering Geology, v. 102p. 214-226, doi: 10.1016/j.enggeo.2008.03.019.

Godt, J.W., Baum, R.L., and Lu, N., 2009, Landsliding in partially saturated materials, Geophysical Research Letters, v. 36, doi:10.1029/2008GL035996.

Harp, E.L., Michael, J.A., and Laprade, W.T., 2006, Shallow-landslide hazard map of Seattle, Washington: U.S. Geological Survey Open-File Report 2006-1139, 23 p., 1 sheet, scale 1:25,000. Laprade, W.T., and Tubbs, D.W., 2008, Landslide mapping in Seattle, Washington, in Baum, R.L., Godt, J.W., and Highland, L.M., eds., Landslides and engineering geology of the Seattle, Washington, area: Geological Society of America Reviews in Engineering Geology, v. XX, p. 37-54, doi: 10.1130/ 2008.4020(02).

Lu, N., and Godt, J.W., 2008, Infinite slope stability under unsaturated seepage conditions: Water Resources Research, v. 44, doi:10.1029/2008/WR006976.

Lu, N., and Godt, J.W., 2013, Hillslope hydrology and stability: Cambridge University Press, New York, $458 \mathrm{p}$.

Lu, N., Godt, J.W., and Wu, D.T., 2010, A closed-form equation for effective stress in variably saturated soil: Water Resources Research, v. 46, 14 p. doi:10.1029/2009WR008646.

Lu, N., Sener, B., and Godt, J.W., 2011, Direction of unsaturated flow in a homogeneous and isotropic hillslope: Water Resources Research, v. 47, doi:10.1029/2010WR010003.

Minard, James P., 1983, Geologic map of the Edmonds East and part of the Edmonds West quadrangles, Washington: U.S. Geological Survey Miscellaneous Field Studies Map MF-1541, scale 1:24,000.

Mirus, B.B., Smith, Joel, Stark, Benjamin, Lewis, York, Michel, A.R., Baum, R.L., 2016, Laboratory testing results: Material strength and hydraulic properties for specimens collected from coastal bluffs near Mukilteo, Washington: U.S. Geological Survey [ScienceBase] data release, available online at http://dx.doi.org/10.5066/F7H13033.

NOAA-USGS Debris Flow Task Force, 2005, NOAA-USGS debris-flow warning system—Final report: U.S. Geological Survey Circular 1283, 47 p.

Reid, L.M., and Lewis, J., 2009, Rates, timing, and mechanisms of rainfall interception loss in a coastal redwood forest: Journal of Hydrology, v. 375, doi: 10.1016/j.jhydrol.2009.06.048.

Salciarini, D., Godt, J.W., Savage, W.Z., Baum, R.L., Conversinia, P., 2008, Modeling landslide recurrence in Seattle, Washington, USA: Engineering Geology, doi:10.1016/j.enggeo.2008.03.013.

Savage, W.Z., Baum, R.L., Morrissey, M.M., and Arndt, B.P., 2000a, Finite-element analysis of the Woodway Landslide, Washington: U.S. Geological Survey Bulletin 2180, 9 p.

Savage, W.Z., Morrissey, M.M., and Baum, R.L., 2000b, Geotechnical properties for landslide prone Seattle area glacial deposits: U.S. Geological Survey Open-File Report 2000-228, 5 p.

Schulz, W.H., 2004, Landslides mapped using lidar imagery, Seattle, WA: U.S. Geological Survey Open-File Report 2004-1396, 11 p.

Schulz, W.H., 2007, Landslide susceptibility revealed by lidar imagery and historical records, Seattle, Washington: Engineering Geology, v. 89, p. 67-87.

Schulz, W.H., Lidke, D.J., and Godt, J.W., 2008, Modeling the spatial distribution of landslide-prone colluvium and shallow groundwater on hillslopes of Seattle, Washington: Earth Surface Processes and Landforms, v. 33, p. 123-141.

Sheets, Bill, 2013, Agencies seek fixes to mudslides, train disruptions: Everett, Washington, The Daily Herald Co., accessed January 31, 2013, at www.heraldnet.com/apps/pbcs.dll/article?AID=/20130131/News01/701319961. 
Tubbs, D.W., 1974, Landslides in Seattle: State of Washington Department of Natural Resources Division of Geology and Earth Sciences, Information Circular No. 52, 15 p., accessed May 19, 2016, at http://file.dnr.wa.gov/publications/ger_ic52_landslides_in_seattle.pdf.

Wayllace, A., and Lu, N., 2012, A transient water release and imbibitions method for rapidly measuring wetting and drying soil water retention and hydraulic conductivity functions: Geotechnical Testing Journal, v. 35, doi: 10.1520/GTJ103596. 